\title{
INTAKE AND DIGESTIBILITY OF LOW-QUALITY \\ NATIVE GRASS HAY BY BEEF COWS \\ SUPPLEMENTED WITH GRADED \\ LEVELS OF SOYBEAN \\ HULLS
}

\author{
By \\ STEPHANIE KIM LONG-MARTIN \\ Bachelor of Science in Agriculture \\ oklahoma state University \\ Stillwater, Oklahoma
}

1984

\author{
Submitted to the Faculty of the \\ Graduate College of the \\ Oklahoma State University \\ in partial fulfillment of \\ the requirements of \\ the Degree of \\ MASTER OF SCIENCE \\ December, 1988
}


Thesis

1988

$4889 i$

cop. 2 


\author{
INTAKE AND DIGESTIBILITY OF LOW-QUALITY \\ NATIVE GRASS HAY BY BEEF COWS \\ SUPPLEMENTED WITH GRADED \\ LEVELS OF SOYBEAN \\ HULLS
}

Thesis Approved:

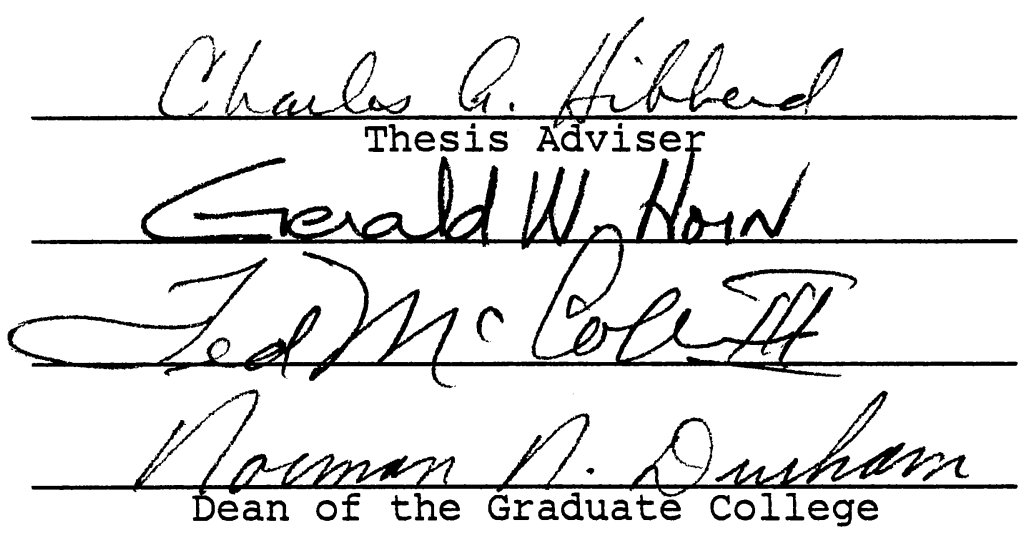




\section{ACKNOWLEDGEMENTS}

First and foremost, I would like extend my sincere thanks to Dr. Charles Hibberd, my advisor and former boss, for his continued assistance, unwavering friendship and patient guidance and advise during my undergraduate years at Oklahoma State University, the course of this study, and preparation of the manuscript.

There are many people, past and present, who make the Animal Science Department here at Oklahoma State University a progressive education and research center. I wish to thank the Animal Science Department for providing the cattle, facilities, equipment and materials necessary to conduct this study. In particular, I would like to thank Dr. Robert Totusek and Faculty for maintaining a well respected graduate program. My thanks especially to Drs. Gerald Horn and Ted McCollum for serving on my graduate committee.

A very special thanks is extended to Les Bourquin for assistance in the laboratory and to Steve welty and the gentlemen of the Nutrition-Physiology Research Barn for care of the experimental animals and help in conducting the trial. I am also grateful for the friendship and assistance extended by my fellow graduate students. In 
addition, a sincere thank you to Dr. Don Wagner, Elizabeth English and Tana McCarter for their friendship and support.

I share this degree with my entire family including my husband, parents, grandparents, sister and brother for their continual support, love and encouragement. A special thank you to all of them for always being there for me. I will never be able to express how much I appreciate each of them. To my husband, Bill, my thanks for standing by me and allowing me to pursue and complete my graduate degree. To my father, a special thank you for insight when I needed it most. In addition, I would like to thank Bill's parents for their continued friendship and support. 
TABLE OF CONTENTS

Chapter

Page

I. INTRODUCTION • . . . . . . . . . . . . . . . . . . 1

II. REVIEW OF LITERATURE • . . . . . . . . . . . . 4

Forage Utilization By Ruminants . . . • . . 4

Native Grass as a Forage Resource. . . 5 Nutritional Quality of Native Range. . . 6 Nurtitional Requirements of Beef Cattle. 10

Voluntary Intake of Forage. . . . . . . 12

Physical Factors . . . . . . . . 13

Ruminal Fermentation . . . . . . 16

Physiological Effects. . . . . . . 18

Supplementation of Grazing Cattle . . . . 19

Ruminal Effects of Supplementation . . 33

Performance Responses to Supplementation. . 40

Alternative Supplemental Feedstuffs . . . . 45

Beet Pulp. •. . . . . . . . . . 46

Citrus Pulp. . . . . . . . . . . . 46

Wheat Bran . . . . . . . . . 47

Rice Bran. . . . . . . . . . . . . 47

Corn Gluten Feed . . . . . . . . . 47

Soybean Hulls. . . . . . . . . . 48

III. INTAKE AND DIGESTIBILITY OF LOW-QUALITY NATIVE

GRASS HAY BY BEEF COWS FED GRADED LEVELS OF

SOYBEAN HULLS. • • • • • • . • • . . . . 51

Abstract. . . . . . . . . . . 51

Introduction. . . . . . . . . . 52

Materials and Methods . . . . . . 53

Results and Discussion. . . . . . . 59

IV. SUMMARY. . . . . . . . . . . . . . 74

LITERATURE CITED. • . . . . . . . . . . . . . 78 
APPENDIX - IN SITU HAY DIGESTIBILITY. • • • • • . • . 90 
I. Chemical Composition of Digestible Fiber Feedstuffs . . . . . . . . . 45

II. Composition and Nutrient Intake of Supplements (Dry Matter Basis) . . . . . . . . 54

III. Chemical Composition of Grass Hay and Soybean Hull Supplements (Dry Matter Basis). . . . 56

IV. Protein Characteristics of Feed Components . . 60

V. Apparent Digestibility of Low-Quality Grass Hay-Soybean Hull Diet Fed to Beef Cows . . . 61

VI. Effect of Soybean Hull Supplementation on Intake of Dietary Constituents by Beef Cows Fed Low-Quality Grass Hay. . . . . . . . . 63

VII. Particulate and Liquid Kinetics of Beef Cows Fed Low-Quality Hay Supplemented with Soybean Hulls. . . . . . . . . . . . . 66

VIII. Characteristics of Ruminal Fluid from Beef Heifers Maintained on Low-Quality Grass Hay Diets Supplemented with Soybean Hulls. . . . . . 68

IX. In Situ Rate and Extent of Disappearance of Low-Quality Grass Hay Suspended in the Rumen of Beef Heifers. . . . . . . . . . . 92 


\section{LIST OF FIGURES}

Figure

1. Ruminal Ammonia Concentrations Post-Supplementation for Beef Heifers fed Graded Levels of Soybean Hulls. . . . . . . . . 67

2. Ruminal pH Post-Supplementation for Beef Heifers fed Graded Levels of Soybean Hulls . . . . . 70 
CHAPTER I

INTRODUCTION

Fall-calving beef cows possess a unique position in the cow-calf producer's management scheme because winter feeding is required to meet both the maintenance requirements of the cow plus increased energy demands for lactation, rebreeding, and gestation. High nutrient requirements combined with the high cost of stored feeds make efficient utilization of resources essential to the economic viability of the enterprise.

Prior to the second World War, little use was made of low-quality roughages but increased feed costs and lack of beef following the war popularized native rangelands (Riggs, 1958). Today, native grass rangeland is the primary feed resource available to cow-calf producers in Oklahoma.

During the months of May and June, the native grasses of Oklahoma supply sufficient quantities of protein and energy to maintain gestating beef cows (Waller et al. 1972; NRC, 1984). But native rangeland is dynamic, possessing characteristics which affect its intake and subsequent utilization. As the forage matures, protein content decreases while crude fiber content increases yielding a 
forage of poor feed quality. During the months of November through February, the nutrient content of standing native grass is lowest (Waller et al., 1972). Thus, cows grazing dormant native grass are typically deficient in protein due to the low crude protein content ( $<4 \%$ crude protein) of the available forage (NRC, 1984; Waller et al., 1972). To offset this deficiency, high-protein feedstuffs such as cottonseed meal or soybean meal have been used. When forage supplies are limited during drought or snow cover, or nutritional demands increase for first-calf heifers or lactating cows, the energy supplied by dormant native grass is surpassed by the needs of the consumer. Traditionally, large quantities ( 1 to $3 \mathrm{~kg} / \mathrm{d}$ ) of grain-based supplements ( $20 \% \mathrm{CP}$ ) have been utilized to meet the increased energy requirement during times of environmental or nutritional stress.

Cereal grains, such as corn, contain large quantities of starch which decrease cellulose digestibility and forage intake (Chase and Hibberd, 1987). Under these circumstances, the overall energy status of the cow may not be improved.

Because of the expense of traditional protein sources and the detrimental effects of starch on forage utilization, a cost feasible, low starch, high energy feedstuff suitable for cattle has been sought. One feedstuff that could meet these criteria is soybean hulls. Soybean hulls (soyhulls, soybran flakes, soybean millrun, 
soybean mill feed) are a by-product of the soybean milling industry. Soybean hulls typically contain $12 \%$ crude protein, 64\% TDN, a large amount of fiber $167 \%$ neutral detergent fiber), and only 2\% lignin (NRC, 1984). Research by Trautman (1987) demonstrated that soybean hulls can be a feasible component of range supplements. Lactating cows grazing native rangeland and supplemented with soybean hulls performed at least as well as cows receiving a corncottonseed meal supplement.

In contrast to cereal grains, soybean hulls offer a digestible fiber energy source which is low in starch and lignin. The effect of soybean hulls on digestibility and intake of low-quality forages, however, is unclear. Thus, the objective of this study was to examine the effect of feeding increased amounts of supplemental soybean hulls on intake and digestibility of low-quality native grass hay and ruminal fermentation in beef cows. 
CHAPTER II

\section{REVIEW OF LITERATURE}

Forage Utilization By Ruminants

Ruminants have forged a vital position in our food chain due, in part, to their unique ability to digest and effectively utilize forages. As widespread as the ruminant livestock industry is, in comparison, little is understood concerning factors controlling intake and utilization of forages by ruminants. In the most basic sense, intake of any feedstuff is determined by characteristics inherent to both the food source and the consumer. The forage composition and structural framework, and the influence of environment affect utilization, as well as the digestion dynamics of the animal consuming the forage and the physiological state of that animal (Allison, 1985). Potentially, every forage could be consumed and utilized in a unique manner whether fed as the sole source of food or supplemented. By elucidation of the common factors that dictate forage consumption and utilization, the producer can make intelligent, efficient use of his forage resource. 


\section{Native Grass as a Forage Resource}

Native range is a valuable commodity to ranchers because it represents an established source of forage, requiring no tillage or seed purchase. With proper management and utilization, rangeland can be and is the foundation of many profitable cow-calf operations. Because of this vital importance to the rancher, the nutritional characteristics of native grass rangeland must be understood to maximize its potential.

Native rangeland is found predominantly in the western United States, including Oklahoma. These rangeland communities are ever-changing, diverse groups comprised of many different species and categories of plants. The primary grasses of native rangeland in Central to Eastern Oklahoma include big and little bluestem, indiangrass and switchgrass (Waller et al., 1972). Grass hay utilized in oklahoma for beef cattle nutritional studies is composed largely of bluestem (little and big), with smaller amounts of switchgrass and indiangrass (Nelson et al., 1952; Pinney et al., 1972; Davis et al., 1977; Hughes et al., 1978a; Trautman, 1987; Gonzalez, 1987 and Scott, 1988).

Chemical Composition. These native rangeland grasses during the months of May, June and, possibly, July contain enough crude protein to satisfy the nutrient requirements for a gestating cow (Waller et al., 1972; NRC, 1984). Yet, phosphorus supplementation is required because soils 
usually lack sufficient phosphorus (NRC, 1984) and produce phosphorus-deficient forages (Fontenot et al., 1953; Meyer and Brown, 1985; Worrell et al., 1986a). Maturity of the forage results in an overall decline in quality due to decreased protein (Scott, 1988) and soluble carbohydrate content, increased lignification and crude fiber content, translocation of nutrients, and morphological changes in the plant tissue structure (Van Soest, 1982; Briggs et al., 1946). Hayes (1985) reported that big bluestem, during the fall, transfers nitrogen from the aboveground leaves to the roots and rhizomes for storage. These changes culminate in a roughage high in fiber and low in crude protein going into the fall and winter months (Riggs, 1958). Consequently, the chemical composition of native rangeland averages 32 to $38 \%$ crude fiber, 2.5 to $6 \%$ crude protein, $.29 \%$ calcium, and $.05 \%$ phosphorus for the months of November through February (Gallup and Briggs, 1948; Nelson et al., 1952; Waller et al., 1972; Chase and Hibberd, 1987 )

Nutritional quality of Native Range

The chemical composition and physical structure of native range forages are directly related to their nutritional value. Some variation in reported nutrient values for native range can be attributed to weather, soil conditions, grass composition (in terms of species and concentration), differences in analytical procedures and 
technique, and methods of sample acquisition. But even with this in mind, native rangeland does show consistent seasonaltrends in nutritional quality.

Seasonal Changes. The nutritional quality of forage plants is affected by numerous environmental factors during the growing season. Factors such as soil fertility, climate, weather, temperature and daylength affect forage quality (Van Soest, 1982). Soil fertility is affected by rainfall, amount and intensity of use and stocking rates. Soil leaching due to rainfall can be beneficial as well as detrimental; while some essential nutrients such as phosphorus are lost, soils leached of silica produce forages with greater digestibility (Van Soest, 1982). Higher temperatures catalyze a faster plant metabolism which draws on the cell contents for fuel resulting in a decreased amount of metabolites within the cell and a measurable increase of structural components (Van soest, 1982). For grasses, higher temperature and increased metabolism are indicative of an overall decrease in forage quality (Van Soest, 1982). Seasonal effects tend to represent the totality of environmental effects on forage composition and concentration for a given area over time.

Structural Components. The effects of environment on the nutritional quality of a forage are demonstrated by a change in the structure of the plant or in the concentration of an entity within the plant. Yet, any change in the composition or concentration of the cell-wall 
complex within native forages can exert an effect on digestibility and intake (Akin, 1979; Van Soest, 1982). A change in the forage chemical constituents or digestibility can be classified as exerting no effect, or resulting in an increase or a possible decrease in intake (Van Soest, 1965; Ellis, 1978). McCollum and Galyean (1985a) and Scott (1988) noted decreased forage intake with advancing season, attributed, in part, to reduced forage digestibility. Elliott and Topps (1963) reported a decrease in dry matter digestibility due to advancing season. Cordova et al. (1978) concluded that intake generally declines with progressing plant maturity which may be attributable to a decrease in forage digestibility.

Nitrogen is a forage component that exerts a direct influence on forage digestibility. Scott (1988) reported decreased crude protein content of native grass pasture for the months of May through July $113.6 \%$ to $9.6 \%$, respectively). Further, Hayes (1985) observed the nitrogen content of big bluestem leaves decreased from $1.6 \%$ in May to $.6 \%$ by July. Decreased forage $N$ may limit the fermentative ability of cellulolytic bacteria in the rumen (Burroughs and Gerlaugh, 1949; Burroughs et al., 1949a; NRC, 1984; Horn and McCollum, 1987). Gallup and Briggs (1948) observed that as the protein content of the prairie hay decreased from 6\% to approximately $3 \%$, TDN content of the hay decreased from 56 to $41 \%$. In addition, crude fiber digestibility decreased from 69 to 56\% and apparent protein 
digestibility decreased from $41 \%$ to zero. Elliott and Topps (1963) noted that as dietary nitrogen content changed, intake, likewise, was positively affected. In addition, nitrogen may be present but inaccessible to ruminant digestion. Worrell et al. (1986a) noted an overall decrease in crude protein content while indigestible nitrogen ( $\%$ of total $N$ ) increased from $9.3 \%$ in June to $18.5 \%$ by september for meadow hay. McCollum et al. (1985c) also reported that insoluble protein content of blue grama increased to $36 \%$ by october.

Van Soest (1982) suggested that intake of low-quality forage depends on the composition of the cell wall complex, the amount of area it occupies and its ability to be digested. Van soest (1965) demonstrated that digestibility influences intake more directly when the cell-wall complex (hemicellulose, cellulose, lignin, fiber-bound protein, cutin, mineral components and lignified nitrogen) accounts for more than 55\% of the dry matter. Essentially, as the cell-wall fraction increases, voluntary intake is more constrained. Low-quality roughages have cell wall fractions ranging from 70 to $90 \%$ (NRC, 1984), thus, the intake of these forages will depend on rumination and the ability of ruminal microorganisms to penetrate and digest the cell-wall complex. Native grass may contain certain entities in its cell: wall such as lignin, silica or cutin which resist ruminal fermentation. 
In an attempt to help clarify the effect of chemical composition on digestibility, Brazle et al. (1979) used electron microscopy to investigate the structural limitations of big and little bluestem grasses to microbial degradation. Bluestem grasses contain waxy cutin, rows of silica, stomata and hair-like extensions on their surface. Ruminal microorganisms locate an accessible area, either one made available by mastication or the stomata. Bacteria then place themselves tangent to the intended area and digest the underlying mesophyll. Areas within the leaf containing cutin (Akin and Amos, 1975; Van Soest, 1982) or silica (Brazle et al., 1979) are left essentially unaltered.

While silica and cutin may be cell wall components which deter digestion of native range forage, nitrogen is one cell wall component which is essential for digestion of range forage. Thus, examination of the components and composition of native grasses at a cellular level for all seasonal periods, may provide essential information towards the elucidation of those factors and their influence on consumption and subsequent digestibility by herbivores.

\section{Nutritional Requirements of Beef Cattle}

To obtain optimal animal performance, one must consider the animal's nutritional necessities, the ability of the diet to satisfy those requirements, and the voluntary intake of the diet (Allison, 1985). Currently, 
the NRC (1984) recommends $.7 \mathrm{~kg}$ of crude protein, $4.8 \mathrm{~kg}$ total digestible nutrients, $23 \mathrm{~g}$ calcium and $18 \mathrm{~g}$ phosphorus per day for a $450-\mathrm{kg}$ cow in the last third of gestation. During lactation, nutrient requirements increase to $.9 \mathrm{~kg}$ crude protein, $5.3 \mathrm{~kg}$ total digestible nutrients, $26 \mathrm{~g}$ calcium and $21 \mathrm{~g}$ phosphorus per day (NRC, $1984)$.

Under range conditions, beef cows may lose body weight during the winter due to the nutritional demands of calving, lactation and rebreeding combined with the inadequate nutrient intake due to low forage quality. Conversely, these cattle may make compensatory weight gains during periods of non- or late lactation. While some weight and condition loss can be tolerated if initial body condition is adequate, the advantages of a 12-month calving interval provide incentives to stabilize cow weight changes during times of increased nutritional requirements (NRC, 1984; Lusby et al.,1976a; Davis et al., 1977).

Since NRC recommendations (1984) represent the beef cow's requirements under optimum conditions, considerations for winter weather and range travel must be considered, particularly if terrain is rough or water sources are located some distance from current grazing areas. These conditions increase or alter the animal's requirement for energy.

Yet, even with compensation for bad weather and range travel, a fundamental problem exists in assessment of the 
nutritional status of range livestock. Attempts to quantify voluntary intake by range cattle are complicated by ever-changing forage composition, lack of reliable methods to measure intake and an inadequate understanding of factors controlling forage intake. This increases the difficulty in effectively meeting their requirements with supplemental feedstuffs.

\section{Voluntary Intake of Forage}

Although evaluation of the nutrient composition of forages and the cow's nutritional needs are important, neither is of much value if the forage is not consumed. Range cattle will consume an estimated 1 to $3 \%$ of body weight, depending on the nutrient content of the forage (Cordova et al. 1978). Pacheco et al. (1983) noted intakes of $2 \%$ or slightly less of body weight for cattle consuming south Texas pastures composed of bluestem $(4.0 \%$ crude protein). McCollum and Galyean (1985a) reported organic matter intake of approximately $2 \%$ of body weight for steers grazing rangeland in New Mexico. Kronberg et al. (1986) observed organic matter intakes of $1.3 \%$ body weight for cows grazing summer rangeland in Montana. Rittenhouse et al. (1970) noted a forage intake value of $57 \mathrm{~g} / \mathrm{kg} \cdot 75$ for cattle grazing winter native range ( $4.1 \%$ crude protein) in Nebraska. Blaxter and Wilson (1962) observed dry matter intakes for steers consuming grass hay ( $8.2 \%$ crude protein) and oat straw (2.6\% crude protein) of 77 and $44 \mathrm{~g} / \mathrm{kg} \cdot 73$, 
respectively. But the factors that determine the amount of forage an animal will voluntarily consume are not completely understood. Physical, microbial and physiological factors all influence the voluntary intake and digestibility of forage.

\section{Physical Factors}

Ruminal Fill. The ruminant will attempt to consume feed to meet nutrient requirements but in the case of native range, the concentration of nutrients is so dilute that voluntary intake may be limited by the physical capacity of the reticulo-rumen (Allison, 1985). Although the rumen is capable of expanding to compensate for larger intakes, voluntary intake of roughages containing less than $10 \%$ crude protein is primarily confined by the capacity of the reticulo-rumen (Ellis, 1978; Van Soest, 1982). Grovum (1986) suggests that, in fact, the cranial sac and reticulum are responsible for sensing fill rather than the rumen as previously believed. Beyond the exact mechanism controlling fill, the mass of forage within the rumen can affect the efficiency of microbial fermentation, thereby, affecting intake (Ellis, 1978). At low levels of protein $(<6 \%)$, intake may also be limited by a protein deficiency (Van Soest, 1982). At higher levels (>10\%), intake may be controlled by size of the gastrointestinal tract (Lyons et al., 1970; Ingalls et al., 1966) although this concept is being challenged (Grovum, 1986). Ruminal fill is also 
affected by the rate of particle size reduction through rumination and fermentation and its subsequent departure via absorption through the ruminal wall or passage to the lower gut (Ellis, 1978; Van Soest, 1982; Allison, 1985).

Particle size. The physical size and shape of the forage affects intake and digestibility (Poppi et al., 1981). Increased intake due to reduced particle size is greatest for low-quality forages which may be due to increased total surface area available for digestion by microorganisms (NRC, 1984) or faster ruminal passage. Ruminal disappearance rate was faster when soybean hulls were ground compared to whole soybean hulls fed to steers (McDonnell et al., 1982). Weston and Hogan (1968) observed increased intake and decreased digestibility when mature ryegrass $(6.1 \%$ crude protein) fed to sheep was ground and pelleted compared to the chopped form. They concluded that the primary reason for the increased intake with pelleting was due to decreased particle size which allowed digesta to leave the rumen more rapidly. This is supported by the observations of Worrell et al. (1986a) where larger particles tended to remain in the rumen for longer periods of time. Particles may have to be reduced to less than $1600 \mu \mathrm{m}$ as minimum size requirement for exiting the rumen (Worrell et al., 1986b; Ellis, 1986). Rather than exerting a direct effect on forage movement, however, smaller particle size may be the result of decreased passage rate allowing for extended degradation (Worrell et al., 1986b). 
Particle size may be considered a factor in the movement of forage through the rumen and voluntary intake, but, passage rate or particle retention, rate and extent of digestion and microbial efficiency may possess more direct influences (Worrell et al., 1986b).

Passage Rate. Passage rate and intake exert positive influences on one another (Worrell et al., 1986a). Worrell et al. (1986a; 1986b), and McCollum and Galyean (1985a) reported decreased passage rates and increased retention times with advancing season (June through August) attributable to declining forage quality. Research by Scott (1988) also reported a decrease in passage rate and increased retention time with advancing season for cows grazing native grass (May through July). Ingalls et al. (1966) noted that as retention time of dry matter increased, intake decreased. Lambs fed alfalfa hay or orchardgrass tended to have shorter retention times and faster solid turnover rates when the forages were fed at 90\% of ad libitum intake compared to $60 \%$ (Varga and Prigge, 1982). Evans (1981) noted that increased forage in the diet increased rumination, solid turnover and saliva production and also suggested a relationship between ruminal solid turnover rate and the amount of $D E$ intake for cattle.

Rate of digestion. Scott (1988) reported a decrease in rate of forage organic matter digestion as native grass matured (May through July). When diets are consumed ad 
libitum extent of degradation is usually lower compared to limit fed diets attributable to increased movement through the rumen (Ganev et al., 1979). While reduced particle size may increase rate of digestion, increased rate of passage decreases total extent of digestion (NRC, 1984).

\section{Ruminal Fermentation}

While the capacity and the movement of material in and out of the reticulo-rumen may be predominant physical constraints limiting intake of low-quality roughages, it is doubtful that they alone control intake. Certain plant characteristics, particularly if they are required by the ruminal microbial population, may affect intake and digestibility of a forage (Thornton and Minson, 1972).

Microbial Requirements. Like their host, ruminal bacteria require nitrogen, energy and minerals for growth, work and reproduction (NRC, 1984). If any of the essential nutrients or cofactors are not present in sufficient amounts, bacterial growth may be reduced. Supplementation to meet the requirements of the microbial population will affect forage fermentability, which may influence forage intake.

Products of Microbial Activity. Ruminal ammonia nitrogen concentrations for sheep consuming mature ryegrass were $3.4 \mathrm{mg} / \mathrm{dl}$ (Weston and Hogan, 1968). Steers maintained on prairie hay had ruminal ammonia concentrations of 1.8 to $3.4 \mathrm{mg} / \mathrm{dl}$ (McCollum and Galyean, 1985b). Cows grazing 
native grass pasture had ruminal ammonia values of 8.4 $\mathrm{mg} / \mathrm{dl}$ decreasing to 4.4 and $2.0 \mathrm{mg} / \mathrm{dl}$ during the months of May through July, respectively (Scott, 1988). Cellulolytic bacteria require a fermentable energy source and ammonia as a source of nitrogen, but with low quality forages, energy and ruminal nitrogen may be insufficient (Bryant, 1973; Ørskov, 1982; Mould and Ørskov, 1983; NRC, 1984) resulting in reduced cellulose digestion (Scott, 1988).

Metabolism by ruminal microbes yields organic acids which represent a waste product for the microbe. For the ruminant, however, volatile fatty acids are a major source of energy (Van Soest, 1982). Molar proportions of volatile fatty acids for roughage diets were reported as $60 \%$ acetic, 25\% propionic, $10 \%$ butyric acid while the remaining $5 \%$ is composed of less predominant volatile fatty acids (Mould and 申rskov, 1983). Scott (1988) reported molar proportions of $78.6 \%$ acetate, $13.2 \%$ propionate and $7.9 \%$ butyrate for cows grazing native grass pasture May through July. Total VFA concentration decreased (106.8 to $88.6 \mu \mathrm{M} / \mathrm{g}$ ) 6 to $12 \mathrm{~h}$ postfeeding with no significant shift in molar proportions for sheep fed high quality forage diets (Ingalls et al., 1966).

Ruminal $\mathrm{pH}$ is controlled by a variety of factors including rumination, VFA production and absorption, and the presence of buffers in the saliva (Van Soest, 1982). Ruminal pH below 6.2 may inhibit cellulolysis and reduce digestibility and intake (Mould and $\varnothing$ rskov, 1983). Steers 
fed alfalfa hay ( 1.4 to $2.4 \%$ of $\mathrm{BW}$ ) maintained ruminal $\mathrm{pH}$ between 6.93 and 6.22 , 0 to $16 \mathrm{~h}$ postfeeding (Adams and Kartchner, 1984). Under most circumstances, ruminants consuming forage diets maintain a ruminal pH between 6.0 and 7.0 (Ørskov, 1982; Van Soest, 1982; McCollum et al., 1985; McCollum and Galyean, 1985b)

Effects of Nutrient Deficiencies. Crabtree and Williams (1971) noted higher intakes for hay containing almost $7 \%$ crude protein compared to straw with only $4 \%$ crude protein. Elliott (1967) suggested that a diet containing less than $10 \%$ crude protein may have detrimental effects on voluntary intake. The low nitrogen content may cause a microbial nutrient deficiency which would decrease forage digestibility. The animal may attempt to compensate with increased forage consumption which may be limited by ruminal fill (Scott, 1988).

Physiological Effects

In addition to the ruminal environment, factors such as physiological status of the cow may influence forage intake. Pregnant beef cows tend to consume less hay than nonpregnant cows during the last half of gestation and consume even less two weeks before calving (Jordan et al., 1973). Gonzalez (1987) reported an 8\% decrease in hay intake three weeks prior to parturition for cows consuming native grass hay. The size of the conceptus may compete for limited abdominal space thereby reducing reticulo- 
ruminal volume. Thus, decreased abdominal space may limit voluntary intake when cows in late gestation consume roughage diets.

Increased consumption is characteristic for cattle following the birth of a calf (NRC, 1984). Jordan et al. (1973) and Gonzalez (1987) both reported large increases in forage intake for cattle immediately following calving. Kronberg et al. (1986) reported $24.4 \%$ and $34.4 \%$ more forage intake for lactating cows compared to dry cows (Hereford and crossbred, respectively) when grazing fescue.

\section{Supplementation of Grazing Cattle}

The effect of various factors on forage utilization can be modulated by supplementation. Under certain circumstances, a particular feedstuff may affect the digestion and consumption of other feeds in the diet (Van Soest, 1982). Intake and digestibility of a feedstuff may be increased (positive associative effect) while, in other cases, decreased (negative associative effect). Strong associative effects, both positive and negative, have been observed with supplementation of low-quality native grass (Van Soest, 1982).

The nutritional quality of native range is generally adequate for dry beef cows during the spring and early summer except for phosphorus (NRC, 1984; Waller et al., 1972). As the forage matures, nutrient content and digestibility diminish so that supplementation may be 
necessary to maintain efficient forage utilization and cow performance (Waller et al., 1972; Furr and Nelson, 1964; Davis et al., 1977). Oklahoma's native range during the winter usually dictates supplementation if optimum beef cow performance is desired (Nelson et al., 1952; Pinney et al., 1972; Trautman, 1987).

Protein is the primary supplemental nutrient for beef cows on dormant grass if forage supply is adequate, the environment is nonstressful and the animal is in a state of moderate nutrient requirements (NRC, 1984; Waller et al., 1972). Yet, even if forage supply is ample, beef cows in early lactation may not consume enough forage to meet their increased energy requirements (Jordan et al., 1973). Under these circumstances, energy supplementation may be required to minimize cow weight and condition losses (NRC, 1984). In addition, when forage availability is limited due to grazing intensity or snow cover, energy as well as protein supplementation may be required to maintain the performance of grazing ruminants. The cow-calf producer must assess the situation in terms of forage resource and expected animal performance to determine an appropriate supplementation program.

Protein Supplementation. When conditions dictate the use of a protein supplement, traditionally, feeds such as soybean meal or cottonseed meal have been used. Highprotein feeds have been utilized because of their ability to increase the voluntary intake and digestibility of low- 
quality forages. Cottonseed cake supplementation (.91 or $1.36 \mathrm{~kg})$ increased the digestibility of dormant $(2.6$ to 4.3 \% CP) native grass (Hobbs et al., 1945). Feeding cottonseed meal (206 g to $1252 \mathrm{~g}$ ) increased dry matter intake of prairie hay from $3.56 \mathrm{~kg}$ to approximately $4 \mathrm{~kg}$ (Gallup and Briggs, 1948). McCollum and Galyean (1985b) also noted an increase in intake of prairie hay from $1.69 \%$ to $2.15 \%$ of body weight when $800 \mathrm{~g}$ of cottonseed meal was added to the hay. Fontenot et al. (1953) demonstrated that feeding $.45 \mathrm{~kg}$ of $20-, 30-$ or 40 -percent protein supplements (decreasing amounts of corn with increasing amounts of cottonseed meal, respectively) to cattle consuming prairie hay ( $5.2 \% \mathrm{CP})$ improved apparent crude protein digestibility. Supplementing cattle with increasing amounts of soybean meal $(1.4 \mathrm{~kg}$ supplement with decreasing amounts of ground barley) increased intake of barley straw (2.8\% crude protein) by $25 \%$ and improved crude fiber and crude protein digestibility (Lyons et al., 1970). Heifers fed wheat straw (3.8\% CP) supplemented with 1, 2, 3 or $4 \mathrm{~g} \mathrm{CP} / \mathrm{kg} \mathrm{BW} \cdot 75$ of soybean meal showed increased straw intake and crude protein and dry matter digestibility $(63.1,69.6,72.6,70.4 \mathrm{~g} / \mathrm{kg} \mathrm{BW} .75$ and $33.8,43.7,55.4$ and 58.6\%, respectively) compared to wheat straw (53.4 dry matter $\mathrm{g} / \mathrm{kg} \mathrm{BW} \cdot 75 ;-6.2 \%$, respectively) consumed alone (Church and Santos, 1981). Cook and Harris (1968) observed that, in most instances, protein supplements (cottonseed meal and soybean meal) increased the intake and 
digestibility of forage protein, cellulose and other carbohydrates. Soybean oil meal $(.17,1.09$ or $1.32 \mathrm{~kg} / \mathrm{d})$ fed to cattle consuming corncobs $(<2 \% \mathrm{CP})$ or timothy hay increased digestibility by 14 and $17 \%$, respectively (Burroughs and Gerlaugh, 1949). Supplementing even a small amount of soybean meal $(.14, .27, .41$ and $.68 \mathrm{~kg} / \mathrm{d})$ to cattle fed prairie hay ( $5.2 \%$ crude protein) increased hay intake $(5.1,6.0,6.2$ and $6.8 \mathrm{~kg} / \mathrm{d}$ respectively) and dry matter digestibility $(41,47,47$ and $50 \%)$ compared to 4.7 $\mathrm{kg} / \mathrm{d}$ hay intake and $39 \%$ dry matter digestibility for cattle fed only prairie hay (Guthrie et al., 1984a). Cattle maintained on low-quality grass hay ( $3.9 \%$ crude protein) fed 0,600 or $1200 \mathrm{~g} / \mathrm{d}$ of a cottonseed, meat and fish meal mix consumed more hay than cattle supplemented with 0,560 or $1120 \mathrm{~g} / \mathrm{d}$ of milo or sustained on hay alone (Hennessy et al., 1983). These studies clearly indicate that under most circumstances, protein is the first limiting nutrient for cattle consuming low-quality grass hay (NRC, 1984).

Wiedmeier et al. (1983) found when steers consumed a diet of $82 \%$ wheat straw with increasing amounts of soybean meal and decreasing amounts of corn $\operatorname{starch}(6.2,7.8,9.3$, $10.9 \%$ crude protein of diets, respectively) fiber digestibility increased. Other experiments (Burroughs et al., 1949a) showed that the replacement of starch with dried skimmilk or a constant"level of starch and increasing amounts of skimmilk improved corn cob digestion. When skimmilk was added to the corn cobs without starch, 
however, corn cob digestion was not altered (Burroughs et al., 1949a). In this situation, a sufficient quantity of $\mathrm{N}$ may have been available for the small amount of fermentable carbohydrates provided in the corn cobs (Horn and McCollum, 1987). Steers fed cottonseed meal (40\% crude protein), wheat midds ( $20 \%$; low starch) or ground wheat (high starch) to supply $.36 \mathrm{~kg} \mathrm{CP} / \mathrm{d}$ consumed more $(3.5 \mathrm{~kg}$ vs $4.5 \mathrm{~kg})$ prairie hay ( $5.4 \%$ crude protein) and increased dry matter digestibility ( 45.9 vs $55.7 \%$ ) irrespective of supplement composition (Arelovich et al., 1983). In this case, the starch contained in the wheat did not exert a detrimental effect on hay intake or digestibility. Perhaps enough $\mathrm{N}$ was available between the hay and. supplement to effectively utilize the energy supplied by the starch.

Cows fed cottonseed hulls ( $4.6 \%$ crude protein) supplemented with $2.7 \mathrm{~kg}$ of supplement $(60 \%$ soybean meal, $30 \%$ sorghum grain and $5 \%$ alfalfa meal pellets) increased dry matter digestibility and intake compared to cows fed $1.3 \mathrm{~kg}$ of supplement (Lusby et al., 1976a). In contrast, Hereford cows grazing tallgrass range fed approximately $1.26 \mathrm{~kg}$ of supplement ( $60 \%$ soybean meal and 5\% dehydrated alfalfa pellets) consumed $2.3 \mathrm{~kg} / \mathrm{d}$ more forage dry matter than cows fed $2.77 \mathrm{~kg}$ of supplement (Lusby et al., 1976b). Rittenhouse et al. (1970) reported that supplemental crude protein had a minimal influence on dry matter digestibility or intake of medium quality forage ( 6.3 to 8.5\% crude protein). Utilization of range forage (January 
through April) that contained over $10.4 \%$ crude protein did not respond to supplemental protein $(1.7 \mathrm{~kg}$ cottonseed cake or $3.5 \mathrm{~kg}$ alfalfa pellets fed every other day; Judkins et al., 1985). Kartchner (1981) reported no significant improvement in intake or digestibility for cattle grazing dormant native range ( 9.4 to $5.2 \%$ crude protein) when protein supplements $(.70 \mathrm{~kg}$ soybean meal or $.75 \mathrm{~kg}$ cottonseed meal) were fed during one trial, but observed an increase in forage intake and digestibility during a second trial when severe weather prevailed. The contrast in results between studies accentuates the difference between drylot performance of cattle versus cattle grazing rangeland under similar feeding regimes.

The type and source of protein used may also yield different results due to differences in the site of protein digestion. Scott (1988) showed that fall-born early weaned calves grazing native grass pasture supplemented with soybean meal (fed to supply $190 \mathrm{~g} / \mathrm{d}$ total protein) gained $7.9 \mathrm{~kg}$ more weight than calves fed corn gluten meal supplement. They suggested that young calves grazing native grass must satisfy ruminal degradable protein requirements before bypass protein becomes useful. Research conducted by Amos and Evans (1976) demonstrated that supplementing low-quality Coastal bermudagrass $18.6 \%$ CP) with different protein sources (urea, sunflower meal or sunflower meal treated with $1 \%$ formaldehyde) had marked effects on digestibility and site of protein concentration. 
The addition of a protein source increased the amount of protein reaching the abomasum, yet, a larger quantity (as a percent of amount fed) reached the abomasum with the sunflower meal or sunflower meal treated with $1 \%$ formaldehyde compared to the urea treatment. In addition, the formaldehyde treatment increased protein flow to the abomasum when compared to the sunflower meal treatment. With the formaldehyde treatment, a larger amount of the protein reaching the abomasum was non-ammonia crude protein.

When protein supplementation improves forage intake or digestibility, protein is considered to be the first limiting nutrient. This phenomenon is often observed when protein is used to supplement cattle consuming low-quality roughages. Yet, under some circumstances, forage intake and digestibility are not improved suggesting that additional protein is essentially wasted because the protein contained in the roughage is sufficient to utilize the fermentable carbohydrate present (Horn and McCollum, 1987 )

Energy Supplementation. When supplemental energy is required, high-starch cereal grains are frequently combined with protein feeds such as cottonseed or soybean meal to formulate $20 \%$ crude protein supplements. Supplementation of forage with high-energy grains containing starch may depress voluntary intake. Campbell et al. (1969) reported decreased digestibility of crude protein and crude fiber in 
kikuyugrass with increased levels $(0,50$ or $100 \mathrm{~g} / \mathrm{d}$ ) of corn fed to ruminants. Cattle fed a diet of corncobs, dried skimmilk and increased increments of starch had decreased apparent dry matter corncob digestion with each addition of starch (Burroughs et al., 1949b). A similar response was observed when cattle were fed a diet containing $4 \mathrm{lb}$ of corncobs, $1 \mathrm{lb}$ of alfalfa hay and either 2 or 4 lb of starch (Burroughs et al., 1949b). Rittenhouse et al. (1970) reported that supplemental energy levels above $.034 \mathrm{Mcal} \mathrm{ME} / \mathrm{kg} \cdot 75$ significantly depressed forage intake, but not forage dry matter digestibility for cattle grazing native range $(<5.3 \%$ crude protein). Decreased forage intake has been associated with decreased solid turnover time which may have allowed for further digestion of consumed forage (Evans, 1981). Kartchner (1981) reported lower daily forage dry matter intake and digestibility for grain-fed $(<2 \mathrm{~kg} / \mathrm{d})$ cows compared to the control (native range) or proteinsupplemented (cottonseed meal or soybean meal) cows. Decreased grazing time has also been observed when a grain supplement $(3.86 \mathrm{~kg}$ of predominantly barley) was fed to cattle grazing native range (Bellows and Thomas, 1976). In a recent trial, low levels of corn supplementation (1 kg) fed to beef cows maintained on low-quality native grass hay ( $4.2 \%$ crude protein) did not cause a pronounced depression in hay digestibility but added increments of corn ( 2 or 3 $\mathrm{kg}$ ) decreased digestibility of hay and cellulose and hay 
intake (Chase and Hibberd, 1987). Similarly, Guthrie et al. $(1984 b)$ reported that steers fed a small amount (1.4 $\mathrm{kg}$ ) of corn supplement ( $80 \%$ corn, $15 \%$ soybean meal) improved hay intake and dry matter digestibility compared to steers fed only prairie hay $(4.2 \%$ crude protein; 5.6 versus $4.1 \mathrm{~kg}$ and 56 versus 50\%, respectively). Campling and Murdoch (1966) fed hay (9\% CP) or barley straw $(3.2 \% \mathrm{CP}$ ) and a $20 \%$ crude protein concentrate mix (predominantly barley and corn) to observe the effect on roughage intake. It was noted that the higher the quality of the roughage, the greater the depression in intake. When higher quality forages are fed with concentrate feeds, intakes are usually depressed (Horn and McCollum, 1987). In contrast, barley straw intake increased with 2, 4 and up to $6 \mathrm{~kg}$ of concentrate. In a similar trial, Crabtree and Williams (1971) fed ewe lambs either oat straw (3.9\% CP) or hay $(6.7 \% \mathrm{CP})$ and a concentrate mix (predominantly wheat and corn). Hay intake decreased with increasing concentrate levels, but oat straw consumption increased with added concentrate up to $25 \%$ of the total diet dry matter, then declined. When increasing amounts of rolled barley $(0,235,470$ and $705 \mathrm{~g}$ dry matter basis) were fed to sheep consuming either a hay or straw diet, different results precipitated dependant on roughage source and crude protein concentration (Lamb and Eadie, 1979). Sheep fed timothy hay with a crude protein content of approximately $8.8 \%$ decreased roughage intake when any amount of barley 
was fed. When timothy hay containing a slightly lower crude protein content $(6.2 \%)$ was supplemented with barley, a slight increase in roughage intake was noted at $235 \mathrm{~g}$ of barley but decreased with further increases in barley supplementation. Intake of roughages with a crude protein level below $4.7 \%$ (timothy straw, $4.69 \%$ and oat straw, 3.5\%) improved by feeding either 235 or $470 \mathrm{~g}$ of barley but at $705 \mathrm{~g}$ of barley roughage intake was either not affected or decreased.

Feeding cattle 9, 18, 27 or $36 \mathrm{~g}$ of concentrate $/ \mathrm{kg} \cdot 73 / \mathrm{d}$ decreased intake of low-quality Rhodes grass hay ( $3.4 \%$ crude protein; Elliott, 1967). Supplemental biuret nitrogen ( 0 or $10 \mathrm{~g} / \mathrm{d}$ ) increased hay intake and cellulose digestibility of low-quality pangolagrass hay $(<4.5 \% \mathrm{CP}$ ) fed to sheep (Fick et al., 1973). In contrast, 0,50 and $100 \mathrm{~g} / \mathrm{d}$ of corn meal, sucrose and starch fed to sheep had no effect on voluntary intake of hay but decreased cellulose digestibility. Supplemental energy fed at $200 \mathrm{~g} / \mathrm{d}$ decreased hay intake. Henning et al. (1980) fed sheep corn straw (4.3\% crude protein) ad libitum with a protein supplement (predominantly casein and fish meal, fed approximately $13.5 \%$ of the amount of straw consumed the day before) and increasing amounts of corn grain $(0,78,156,235,313$ and $393 \mathrm{~g} / \mathrm{kg})$. Although, the protein supplement was supplied to insure adequate ammonia and branched chain VFA supply and $\mathrm{pH}$ was not a significant factor, as the amount of corn 
(over $156 \mathrm{~g} / \mathrm{kg}$ ) increased, straw intake decreased and the amount and percent of cellulose and hemicellulose digested decreased. In addition, the number of cellulolytic bacteria decreased with increased corn supplementation. In contrast, when alfalfa hay was used as the sole roughage source, additions of starch $(2,4$ or 6 lb) did not significantly affect hay digestion (Burroughs et al., 1949b). Kane et al. (1959) found that 6 lb of starch did not decrease alfalfa dry matter and protein digestibilities when a 20-day preliminary period was allowed. An adaptation period of this length may have allowed the microbial population to adjust to the utilization of both substrates.

When a forage contains less than $3.9 \%$ crude protein, supplementation with an energy source may increase forage intake. This may be due to the rectification of a protein or other nutrient deficiency. Forages containing between 4.2 and $6.2 \%$ crude protein, when supplemented with a small amount of energy $(.25$ to $1 \mathrm{~kg})$ may increase forage intake, while larger amounts may not affect or may decrease forage intake and digestibility. Forages with greater crude protein contents usually have decreased intakes when supplemented with energy feeds such as corn or barley. Horn and McCollum (1987) summarized the effect of energy concentrates fed to supplement low-quality roughages by stating that supplying a readily fermentable carbohydrate 
to a substrate containing a small amount of $\mathrm{N}$ such as lowquality roughages may deplete the ruminal ammonia pool.

High energy feeds such as corn may affect forage intake and digestion by decreasing grazing time. Decreased grazing time would increase the proportion of concentrate present in the rumen which could decrease $\mathrm{pH}$ and increase microbial washout and microbial detachment.

el-Shazly et al. (1961) offered four theories to explain the effect of starch supplementation on cellulose digestion: 1) starch-digesting microorganisms produce a material which hinders cellulose digestion; 2) $\mathrm{pH}$ may decrease due to starch fermentation to a point which discourages cellulose digestion (microbial washout and detachment catalyzed by a pH below 6.2; Horn and McCollum, 1987); 3) starch-digesting microorganisms compete for and obtain essential nutrients, and 4) a larger number of starch-digesting microorganisms in the rumen of cattle consuming high-starch rations. Ruminal pH may be a contributing or temporary agent but is not likely to be the foremost factor. The addition of urea to a diet of hay and corn ( 2 to 1 ratio) alleviated most of the depression in cellulose digestion, suggesting that adequate quantities of ruminal nitrogen may alleviate detrimental effects of starch on cellulose digestion.

Supplementation with high starch energy feeds may also create a nitrogen limitation or provide a preferred 
substrate compared to the available forage (Chase and Hibberd, 1987; Horn and McCollum, 1987).

Alternative Energy Sources. Because of the possible detrimental effects of starch on the intake and digestibility of forage, alternative sources of supplemental energy have been examined. Johnson et al. (1962) conducted digestion trials with sheep fed soybran flakes alone and with poor quality timothy hay. Cellulose, crude fiber and protein digestibilities were improved by feeding soybran flakes with timothy hay $(6.3 \%$ crude protein) compared to either fed separately or feeding soybran flakes or timothy hay with corn. Hintz et al. (1964) found no significant differences in dry matter or crude fiber digestibilities when feeding soybean hulls with hay in varying ratios $(1: 1,2: 1$ or $3: 1)$. In a digestion trial with lambs, crude fiber digestibility increased (from $52 \%$ to $67 \%$ ) with increased quantities of citrus pulp substituted for corn in the ration, suggesting that citrus pulp fiber does not possess the negative associative effects associated with corn (Bhattacharya and Harb, 1973). In a similar experiment, sheep were fed a control ration of $60 \%$ corn or a ration containing increasing amounts beet pulp $(30 \%$ beet pulp, $30 \%$ corn; $45 \%$ beet pulp, $15 \%$ corn; $60 \%$ beet pulp) with the balance of the diet comprised of wheat bran, peanut oil meal, alfalfa hay, salt, limestone and bonemeal (Bhattacharya and Sleiman, 1977). No significant change in crude protein or apparent dry matter 
digestibility was detected even at $60 \%$ beet pulp. In addition, TDN content remained essentially the same. Additions of soybean mill run (substituted for corn) increased acid detergent fiber and cellulose digestibilities when fed with alfalfa silage to dairy cows (MacGregor et al., 1976). Crude fiber digestibility increased with increasing amounts $(10,40$ and $70 \%$ of the dietary dry matter) of citrus pulp or soybean mill feed compared with ground corn for sheep consuming forage (Sudweeks, 1977). When supplements composed of ensiled ground cornstalks (38\% of the supplement) and either soybean hulls (whole, ground or whole-pelleted) or rolled corn as an energy source were fed to lambs, the soybean hull supplements increased neutral detergent fiber digestibilities compared to rolled.corn (Merrill and Klopfenstein, 1985).

Highfill et al. (1987) fed cattle low-quality fescue hay ( $9.1 \%$ crude protein) supplemented with corn-soybean meal, soybean hulls, corn gluten feed, or a citrus pulpsoybean meal mix. Dry matter digestibility was not affected by treatment, but cows fed the soybean hulls or corn gluten feed had greater neutral detergent fiber digestibilities compared to the other supplements. In a second trial, the same diets were used except a soybean hull-wheat mix was utilized in place of the citrus pulpsoybean mix. Again, no differences were observed for dry matter digestibility and digestibilities for acid and 
neutral detergent fiber were higher for cattle consuming soybean hulls. In an in situ study, rate and extent of disappearance of corn fiber and soybean hulls were higher than when compared to oat hulls or cottonseed hulls (Hsu et al., 1987). In a subsequent digestion trial with sheep, corn fiber and soybean hulls had higher neutral detergent and acid detergent digestibilities than oat hulls or cottonseed hulls.

Additions of digestible fiber sources such as beet pulp, citrus pulp and soybean hulls may improve fiber digestibility. In addition, soybean hulls and corn fiber provided increased fiber digestion compared to oat hulls or cottonseed hulls. It is possible that highly digestible fiber sources may not actually be more digestible compared to corn, rather it is possible that these fibrous energy sources do not cause the negative associative affects common when supplementing with high starch feeds such as corn (Chase and Hibberd, 1987; Horn and McCollum, 1987).

\section{Ruminal Effects of Supplementation}

Source of supplementation may also affect ruminal function. The ideal supplement, whether fed to provide protein, energy or both, will cost effectively produce the desired result fed at a particular rate. The focus of those results may entail an increase or decrease in forage intake and digestibility, as previously discussed, or it may represent a beneficial or detrimental change in those 
factors in the rumen which ultimately affect forage intake and digestibility. By examining ruminal fermentation patterns and products, a clearer understanding of intake and digestibility control will be gained.

Passage Rate. Cattle fed barley straw with increasing levels of soybean meal $(1.4 \mathrm{~kg}$ supplement containing decreasing amounts of ground barley) reported no significant difference between treatments for ruminal turnover time, although, at the highest level of supplemental protein, ruminal turnover time tended to increase (Lyons et al., 1970). Retention time was reduced from $75.8 \mathrm{~h}$ to $54.9 \mathrm{~h}$ when steers fed prairie hay were supplemented with $800 \mathrm{~g}$ of cottonseed meal (McCollum and Galyean, 1987b). As the level of corn supplementation (0, 1,2 , or $3 \mathrm{~kg}$ ) was increased for cattle fed native grass hay, particulate passage rate decreased from 3.9 to $3.7 \% / \mathrm{h}$ (Chase and Hibberd, 1987). Evans (1981) reported that increased diet energy density may decrease the rate of solid turnover in the rumen. Ganev et al. (1979) reported a slower rate of passage for concentrate versus foragebased diets. This may help explain why feeding increased amounts of a high energy feed such as corn causes a depression in forage intake.

Rate of digestion. In situ dry matter disappearance of low quality prairie hay ( $4.9 \%$ crude protein) was increased from $18.9 \%$ to $35.7 \%$ and $44.2 \%$ for steers supplemented with 0,241 and $604 \mathrm{~g}$ of soybean meal, 
respectively (Barton and Hibberd, 1984). Supplementing steers fed prairie hay with $800 \mathrm{~g}$ of cottonseed meal increased in vitro dry matter digestibility compared to values for steers receiving only prairie hay at all sampling times (McCollum and Galyean, 1985b). Cows fed prairie hay and supplemented with .55 (control) or $1.48 \mathrm{~kg}$ of cottonseed meal, $3.45 \mathrm{~kg}$ of soybean hulls or $2.6 \mathrm{~kg}$ of either corn/cottonseed meal or soybean hull/cottonseed meal supplement differed little between treatments (between 3.0 to $3.8 \% / \mathrm{h}$ ) for hay organic matter digestion rate (Trautman, 1987). In contrast, Chase and Hibberd (1987) reported decreased rates of digestible hay and NDF disappearances (approximately $3.8,3.3,2.0$, and $1.4 \% / \mathrm{h}$ for both) for cows fed increasing amounts of corn supplement $(0,1,2$ or $3 \mathrm{~kg}$, respectively).

Ammonia. Supplementation schemes that alter rate of passage and digestion may also affect ruminal

fermentability. Lyons et al. (1970) fed cattle barley straw, and noted that ruminal ammonia concentrations tended to increase with increased levels of soybean meal supplement. Ammonia concentrations increased .7 to 6.9 $\mathrm{mg} / \mathrm{dl}$ when steers fed predominantly wheat straw $(82 \%$ of the diet) were supplemented with soybean meal and corn (increasing soybean meal with decreasing corn) to provide $6.2,7.8,9.3$ and $10.9 \%$ crude protein in the diet, respectively (Wiedmeier et al., 1983). Cattle consuming low-quality hay ( $3.9 \%$ crude protein) alone or supplemented 
with milo $(0,560$, or $1120 \mathrm{~g} / \mathrm{d})$ had ruminal ammonia concentrations of 1 to $1.5 \mathrm{mg} \mathrm{N} / 100 \mathrm{ml}$ (Hennessy et al., 1983). Ruminal ammonia concentrations increased ( 6.9 to $7.6 \mathrm{mg} \mathrm{N} / 100 \mathrm{ml}$ ) when cattle consumed hay with a protein supplement of cottonseed meal, fish and meat meal (Hennessy et al., 1983). Supplemental cottonseed meal ( $800 \mathrm{~g})$ increased ruminal ammonia concentrations of steers fed prairie hay ranging from 1.8 to $3.4 \mathrm{mg} / 100 \mathrm{ml}$ to greater than $5.4 \mathrm{mg} / 100 \mathrm{ml}$ (McCollum and Galyean, 1985b). Steers consuming prairie hay supplemented with $.36 \mathrm{~kg}$ of crude protein from cottonseed meal, wheat midds (low starch) or ground wheat increased ruminal ammonia concentrations 3.56, 2.64 and $4.44 \mathrm{mg} / 100 \mathrm{ml}$, respectively (Arelovich et al., 1983). In this trial, any source of protein improved ruminal ammonia concentrations compared to the control (.35 $\mathrm{mg} / 100 \mathrm{ml})$.

Supplementing low-quality forages with a protein supplement increases the concentration of ruminal ammonia. In contrast, supplementation of native grass hay with 1,2 or $3 \mathrm{~kg}$ of corn significantly decreased ammonia concentrations from 2.2 to $1.1, .88$ and $.61 \mathrm{mg} / \mathrm{dl}$, respectively (Chase and Hibberd, 1987).

Volatile Fatty Acids. Low-quality grass hay $13.9 \%$ crude protein) yields low VFA concentrations ( $86 \mathrm{mmol} / \mathrm{l}$ ) with acetate as the predominant volatile fatty acid (Hennessy et al., 1983). Molar proportions of acetate decreased slightly from $72 \%$ to $69 \%$, while molar proportions 
of propionate and butyrate tended to increase slightly from 17 to $18 \%$ and 9 to $10 \%$, respectively, for steers fed prairie hay ( $6.1 \%$ crude protein) and supplemented with 800 $g$ of cottonseed meal (McCollum and Galyean, 1985b). Volatile fatty acid concentrations increased 42.5, 46.5, 55.2 and $60.8 \mu \mathrm{mol} / \mathrm{ml}$ for steers fed wheat straw $(82 \%$ of the diet) and supplemented with increasing amounts of soybean meal $(7.0,10.1,13.1$ and $16.3 \%$ of the diet) and decreasing amounts of corn starch $(11.5,8.4,5.4$ and $2.2 \%$ of the diet), respectively (Wiedmeier et al., 1983). Molar proportions of acetate and butyrate were similar across all diets at $72.7 \%$ and $6.4 \%$, respectively, while propionate decreased 18.7 to $17.8 \%$. Increasing levels of corn supplementation $(0,1,2$, or $3 \mathrm{~kg})$ resulted in a molar proportion decrease in acetate from $74 \%$ to $67 \%$ and a molar proportion increase in butyrate from 5.7 to $7.6 \%$, respectively (Chase and Hibberd, 1987). Propionate only tended to increase (20 to $23 \%$ ) with increased amounts of corn in the diet. Lamb and Eadie (1979) reported increasing VFA concentrations ( 62.4 to $89.5 \mathrm{meq} / \mathrm{l})$ for sheep consuming timothy hay and increasing amounts of rolled barley $(0,200,400$ or $600 \mathrm{~g})$. Molar proportions of acetic acid decreased ( 73.9 to $66.2 \%$ ) while butyric acid increased from 7.9 to $15.1 \%$. Propionic acid showed small fluctuations but averaged approximately 18\% across all levels of barley fed. Sheep fed corn straw (4.3\% crude protein), a protein supplement and increasing amounts of 
corn showed little change in VFA molar proportions. Acetic acid fluctuated between 63 to $79 \%$, propionic acid was between 14 to $25 \%$ and a slight increase in butyric acid was noted with increasing amounts of corn fed (Henning et al., $1980)$.

Hsu et al. (1987) reported low ruminal pH (5.36) and high total volatile fatty acid concentrations (134.8 mM) for sheep fed soybean hulls suggesting that soybean hulls are highly fermentable. Trautman (1987) reported that cows fed low-quality native grass hay and supplemented with 1.48 $\mathrm{kg}$ of cottonseed meal, $3.45 \mathrm{~kg}$ of soybean hulls or $2.6 \mathrm{~kg}$ of either a corn/cottonseed meal or soybean hull/cottonseed meal supplement increased total volatile fatty acid concentrations while supplements containing soybean hulls provided the highest concentrations of $114 \mathrm{mM}$ versus $94 \mathrm{mM}$ for the control $(.55 \mathrm{~kg}$ cottonseed meal). Increasing the amount of soybean hulls present in the diet also decreased molar proportions of acetate while increasing the molar proportions of butyrate compared to the control ( 80.1 to $78.5 \%$ and 5.6 to $6.7 \%$, respectively). In dairy rations, soybean mill run substituted for corn gave similar molar percentages of $66 \%$ acetate, $19 \%$ propionate and $16 \%$ butyrate across all treatments (MacGregor et al., 1976). Citrus pulp ( $<60 \%$ of the diet) and hay fed to dairy cattle resulted in molar proportions of volatile fatty acids of $66 \%$ acetate, $15 \%$ propionate and $14.5 \%$ butyrate up to $4 \mathrm{~h}$ postfeeding (Wing, 1975). 
Any source of supplementation increased the concentration of ruminal volatile fatty acids although the type of supplement used produced different molar proportions of the predominant acids acetate, propionate and butyrate. High fiber feeds such as soybean mill run and citrus pulp gave lower molar proportions of acetate and higher molar proportions of butyrate compared the more traditional supplement feeds.

Ruminal pH. McCollum and Galyean (1985b) reported ruminal pH values of approximately 6.4 for cattle consuming prairie hay supplemented with $800 \mathrm{~g}$ of cottonseed meal. Lamb and Eadie (1979) reported decreasing $\mathrm{pH}$ values of $6.40,6.28,5.94$ and 5.82 for sheep fed timothy hay $19.0 \%$ crude protein) and $0,200,400$ or $600 \mathrm{~g}$ of rolled barley, respectively. Heifers fed low-quality ( $4.2 \%$ crude protein) native grass supplemented with $0,1,2$, or $3 \mathrm{~kg}$ of ground corn daily had ruminal pH values between 6.3 and 6.8 , although at 2 and $3 \mathrm{~kg}$ of corn, ruminal pH tended to remain lower compared to the control $(0 \mathrm{~kg}$ corn) or $1 \mathrm{~kg}$ of corn treatment (Chase and Hibberd, 1987). Supplements containing corn or soybean hulls tended to have ruminal $\mathrm{pH}$ values below 6.2 four to twelve $h$ postfeeding (Trautman, 1987).

Performance Responses to Supplementation

As early as 1932, scientists noted that beef cows grazing New Mexico winter range supplemented with 1 lb of 
cottonseed meal gained more weight than cows supplemented with 1 lb of ground corn (Lantow, 1932). Knox and Watkins (1958) supplemented gestating cattle on New Mexico rangeland with $1 \mathrm{lb}$ ground corn or cottonseed pellets, or $1.25 \mathrm{lb}$ cottonseed meal-dehydrated alfalfa meal mix (amounts were doubled during lactation). Cows consuming the grain supplement lost less weight than the control (range forage only) while cows consuming cottonseed pellets gained more weight than the grain-fed cattle. In a winter feeding trial, cattle grazing Nevada semi-desert range gained .09 and $.14 \mathrm{lb} / \mathrm{d}$ when supplemented with $1 \mathrm{lb}$ of $\mathrm{a}$ protein meal (soybean or cottonseed meal) or $3 \mathrm{lb}$ of alfalfa, respectively (Speth et al., 1962). Cochran et al. (1986) observed cows consuming only prairie grass lost body condition and weight (down to $4.6 ; 11 \mathrm{~kg}$, respectively) while cows receiving either $1.25 \mathrm{~kg}$ of alfalfa cubes or .9 $\mathrm{kg}$ of a cottonseed meal-barley cake gained or maintained body condition and weight (5.3; 14 to $24 \mathrm{~kg}$, respectively). Cattle fed $1 \mathrm{lb}$ barley/d maintained their weight while unsupplemented cows lost.2 lb/d. Lyons et al. (1970) observed that cattle consuming only barley straw lost significantly more weight during the winter than cattle fed increased levels of soybean meal. Cows grazing native range lost less weight when supplemented with soybean hulls ( $7.8 \mathrm{lb})$ than cows fed cottonseed meal $(1.3$ or $3.3 \mathrm{lb})$ or cottonseed meal-corn mix $(6.2 \mathrm{lb})$ through the winter (Hibberd et al., 1986). Cows maintained on native range 
for two winter feeding trials lost less weight and body condition when supplemented with $3.45 \mathrm{~kg}$ of soybean hulls or $2.6 \mathrm{~kg}$ of either a corn/cottonseed meal or soybean hull/cottonseed meal supplement compared to cows receiving $1.5 \mathrm{~kg}$ of cottonseed meal (Trautman, 1987). During the first year, cows fed the soybean hull supplement lost less weight compared to cows receiving the corn/cottonseed meal supplement. In year two, however, the reverse occurred. Differences in forage quality and weather during the two winters was suggested as a possible explanation. But cows receiving the soybean hull supplement lost less body condition than cows fed the corn/cottonseed meal supplement during both winters.

Pinney et al. (1972) noted that as winter weight loss increased, gains the following summer increased and that these changes were directly related to winter feed level for cattle (< 5-year old) grazing native range. Lusby et al. (1976b) noted that cows supplemented through the winter lost $10-15 \%$ of their fall weight but made compensatory gains the following summer.

Minimizing weight fluctuation year round should allow for more efficient rebreeding (Davis et al., 1977; Rakestraw et al., 1983). Cows that lost $20 \%$ of their full weight loss during the winter either required a longer time to return to estrus or more services for conception (Hughes et al., 1978b; Rakestraw et al., 1983). Hughes et al. (1978b) noted that cows (less than 6 years old) grazing 
native range had earlier calving dates when fed a high level of supplementation (cottonseed meal-milo mixture) designed to maintain weight through the winter. The effects of supplementation appear to be greater for the first four calf crops (Hughes et al., 1978b).

Wagner et al. (1965) fed soybran flakes $(30 \%$ of a concentrate mixture) with corn silage and alfalfa hay to lactating dairy cows and reported equal performance in terms of milk yields and body weight gains when compared with oats or citrus pulp. MacGregor (1976) also reported no difference between soybean mill run or corn for net energy, milk production or body weight change, suggesting that soybean mill run is equivalent to corn as a energy source for lactating cows. In another lactation trial, dairy cows were fed a diet containing $4 \mathrm{~kg}$ of alfalfa hay and either $57 \%$ barley and $10 \%$ beet pulp or $55 \%$ beet pulp. Researchers noted no change in hay intake, milk production or body weight change even when the diet contained $55 \%$ beet pulp (Bhattacharya and Sleiman, 1977).

Davis et al. (1977) concluded from an experiment with beef cows grazing dormant native range that energy (1.4 or $2.7 \mathrm{~kg} / \mathrm{d}$ of milo) was more important than protein $(.7 \mathrm{~kg} / \mathrm{d}$ soybean meal) for reproduction, particularly during the first five years. Cows maintained on dormant native range supplemented with $1.4 \mathrm{~kg} / \mathrm{d}$ of alfalfa hay conceived earlier when supplemented with $2.7 \mathrm{~kg} / \mathrm{d}$ of milo compared to $.7 \mathrm{~kg} / \mathrm{d}$ of soybean meal. Bellows and Thomas (1976) reported a 
decreased fall pregnancy rate for cows fed $3.86 \mathrm{~kg} / \mathrm{d}$ of a predominantly barley grain supplement, before or during lactation and rebreeding, compared to cows solely consuming Montana range forage. Both periods of supplementation increased services per conception and reduced conception rate which contributed to the decrease in pregnancies. The source of required energy should be an important consideration, particularly, during the first four or five calf crops. Merrill and Klopfenstein (1984) conducted two grazing studies (cattle on brome pasture or cornstalks) to study the effects of no supplement compared with feeding corn or soybean hulls. Cattle grazing cornstalks gained more when supplemented with either corn or soybean hulls, yet cattle fed soybean hulls gained slightly more weight than cattle fed corn. Up to $50 \%$ corn bran was substituted for corn with either fescue or corn silage with no effect on daily gain and only a slight depression in intake with the corn silage diet (Faulkner et al., 1986). When cows grazing winter range were supplemented with .5 or $.9 \mathrm{~kg}$ soybean meal, .47 soybean meal plus .93 corn gluten feed kg or $2 \mathrm{~kg}$ corn gluten feed, cows consuming $.5 \mathrm{~kg}$ soybean meal lost $25 \mathrm{~kg}$ of body weight and had a conception rate of $72 \%$ while cows consuming the other supplements maintained or slightly increased their weight and improved conception rates to 79,83 and $84 \%$, respectively (Fleck et al., 1987). In a subsequent trial, heifers grazing summer range supplemented with $.55 \mathrm{~kg}$ soybean meal, $.82 \mathrm{~kg}$ soybean 
meal/corn gluten feed or $1.27 \mathrm{~kg}$ corn gluten feed increased weight gains compared to the control (range only) suggesting corn gluten feed can be fed alone or combined with soybean meal as a range supplement Fleck et al. (1987).

Low-quality forages are unable to nutritionally support beef cows through the winter months when fed as the sole source of feed. Although winter weight losses are gained back during the summer, extreme weight fluctuations may decrease the performance capability of the cow, particularly when considered over a lifetime. Supplementing these low-quality forages with protein and energy provides for marked improvement in beef cattle performance. Considerations must also be made for the type of supplement to be utilized as dictated by cost, nutritional needs and performance expectations.

\section{Alternative Supplemental Feedstuffs}

The milling process for refinement of many feeds and products into a useful form, concomitantly, yields byproducts presently considered waste materials. A variety of these by-product feedstuffs possess the potential to be used effectively in ruminant livestock rations. The chemical composition of a few of these feedstuffs is presented in Table I. 
TABLE I. CHEMICAL COMPOSITION OF DIGESTIBLE FIBER FEEDSTUFFs ${ }^{a}$

\begin{tabular}{|c|c|c|c|c|c|c|c|}
\hline Item & $\begin{array}{c}\text { Crude } \\
\text { protein }\end{array}$ & TDN & $\begin{array}{l}\text { Cell } \\
\text { Wall } \\
\end{array}$ & Cellulose & Hemicellulose & Lignin & $\begin{array}{c}\text { Ether } \\
\text { Extract }\end{array}$ \\
\hline $\operatorname{Corn}^{b}$ & 10 & 90 & 11.6 & 2.5 & 8.6 & .9 & 4.2 \\
\hline Beet pulp & $8-11$ & 74 & 56 & 22.8 & 21.0 & 2.4 & .6 \\
\hline Citrus pulp & $7-8$ & 83 & 23 & & & 2.9 & 3.6 \\
\hline Corn gluten feed & d 20-25 & 83 & 50 & 8.6 & 39.0 & 2.0 & 3.7 \\
\hline Rice bran & 14 & 68 & 30 & 11.0 & 15.0 & 4.2 & 15.3 \\
\hline Soybean hulls & $9-13$ & 64 & 68 & 43.3 & 18.0 & 2.5 & 2.2 \\
\hline Wheat bran & 17 & 70 & 48 & 11.0 & 34.0 & 3.3 & 4.6 \\
\hline
\end{tabular}

avalues compiled from Bath, 1981; Bhattacharya and Harb, 1973;

Bhattacharya and Sleiman, 1977; Castle et al., 1966; Cullison, 1975; Fleck, 1987; Hintz et al., 1964; Hsu et àl., 1987; Loy, 1986; Nocek and Hall, 1984; NRC, 1984; Quicke et al., 1959; U.S.-CTFC, 1982; Van Soest, 1982; Wagner et al., 1965.

$b_{\text {Corn included as a reference. }}$ 
Beet Pulp

Beet pulp is a byproduct of sugar beet processing and is considered an energy feed. Bentley et al. (1958) showed by in vitro techniques that the fiber contained in beet pulp is highly digestible (90 to $96 \%$ ). Although beet pulp is very palatable to ruminants, unless previously dehydrated, the high water content of wet beet pulp makes it economically infeasible to transport any distance from the processing site (Bath, 1981). Beet pulp is considered a bulky feed and contains properties which have a mild laxative effect when fed to livestock (Cullison, 1975).

\section{Citrus Pulp}

Citrus pulp is also considered a by-product energy feed and is defined as a combination of the ground peel, inside residue, and occasional, cull citrus fruits and may contain whole citrus seeds or dried citrus meal (AAFCO, 1981). The nutritive value of citrus pulp is derived from its concentration of nitrogen-free extract (73\%), sugar (14\%) and pectins (Kirk and Davis, 1954; Bhattacharya and Harb, 1973). Trials on native pasture have shown that citrus pulp is a palatable feed that can be fed all year (Kirk and Davis, 1954). 
Wheat Bran

Wheat bran is composed of the seed coats containing the wheat kernel (Bath, 1981). It is a very palatable feed to cattle (Morrison, 1959; Bath, 1981) and is often chosen as a livestock feed because of its bulky nature (Crampton and Harris, 1969; Cullison, 1975). In additionm, wheat bran may be utilized because of its properties as a mild laxative (Cullison, 1975). Wheat bran is also considered an excellent source of phosphorus (Cullison, 1975; NRC, 1984)

\section{$\underline{\text { Rice Bran }}$}

Rice bran originates from the processing of rice grain for human consumption (Bath, 1981). Besides containing the pericarp or bran layer, the by-product additionally includes the germ from the rice grain and hull fragments remaining after the milling process (AAFCO, 1981). Rice bran is not as palatable to livestock when compared to other by-product feeds but it is considered an excellent source of phosphorus and energy (Cullison, 1975).

\section{Corn Gluten Feed}

Higher consumer demand for high fructose corn syrup and other products have resulted in a concomitant increase of high fiber by-products such as corn bran and corn gluten feed (Faulkner et al. 1986; Loy, 1986). Corn gluten feed 
is a mixture of approximately $65 \%$ bran and $35 \%$ syrup-like matter produced from soaking the corn to remove most of the soluble nutrients (DeHaan et al. 1983; Loy, 1986; Green et al., 1987). A more descriptive definition is provided by (AAFCO, 1981) as the residual after the extraction of the starch, gluten and germ. Corn gluten feed, however, contains little or no gluten (Loy, 1986). Corn gluten feed in an in vitro study had a faster rate and extent of neutral detergent fiber disappearance compared to corn bran, wheat bran and beet pulp (DeHaan et al., 1983). The protein in corn gluten feed is degraded faster than protein present in soybean meal (Green et al., 1987).

Soybean Hulls

Soybean hulls (soybean mill run, soybean mill feed) are by-products of the soybean milling industry consisting primarily of the outer covering (seed coat) of the soybean and bean meats that remain intact during the milling process (AAFCO, 1981). Soybean hulls are separated from the bean after the whole intact soybean is screened and then cracked into 4 to 6 pieces between pairs of sequential rollers (Alden, 1975). Since they are light in density, the hulls are then air separated from the cracked bean meat.

Soybean hulls generally contain 12 to $14 \%$ crude protein which may represent the presence of some soybean meal in commercial loads of soybean hulls and are low in 
soluble carbohydrates (Merrill and Klopfenstein, 1985). In vitro techniques demonstrate that cellulose contained in soybean hulls and soybean flakes is 96 to $97 \%$ digestible. Johnson et al. (1962) reported organic matter and cellulose digestibilities of approximately 70.4 and 71.4 percent, respectively, when fed as the sole source of feed in digestion trials with sheep. In a similar trial, cellulose digestibility was only 54 to 59\% (Bentley et al., 1958; Quicke et al., 1959). They suggested, based on the stool softness, passage rate was too fast to allow for greater cellulose digestion. This theory is supported by in situ work where $96 \%$ of the cellulose contained in the soybean hulls had disappeared by $30 \mathrm{~h}$. Wagner et al. (1965) reported that soybran flakes had a TDN value of $64.8 \%$ and a crude fiber digestibility of $70.9 \%$ when fed to lactating dairy cows as the sole source of feed.

Johnson et al. (1962) reported that soybran flakes appear to be equal in energy value to corn to replace either corn or roughage in a wintering ration (predominantly meadow silage, hay and corn) for heifers. McDonnell et al. (1982) found that fiber intake and digestibility was higher for soybean hulls compared to corn in a digestion trial with lambs fed corn stalkage. In a digestion trial with steers fed corn stalkage (with corn or soybean hulls at $0,12.5,25$ or $50 \%$ of the ration), fiber digestibility increased with increasing levels of soybean hulls while corn decreased fiber digestibility (McDonnell 
et al., 1982). Faulkner et al. (1986) found that source of supplement (soybean hulls, corn or corn bran) had no effect on daily gain when fed to growing steers on fescue hay silage or corn silage. Intake tended to be highest for the corn silage, fescue hay silage diets supplemented with soybean hulls. Although supplementation with soybean hulls had slightly decreased feed conversion, if cost permits, soybean hulls would be a suitable alternative for energy supplementation. 
CHAPTER III

\author{
INTAKE AND DIGESTIBILITY OF LOW-QUALITY \\ NATIVE GRASS HAY BY BEEF COWS \\ SUPPLEMENTED WITH GRADED \\ LEVELS OF SOYBEAN HULLS
}

\begin{abstract}
Twelve Hereford cows and four mature, ruminallycannulated Hereford X Angus heifers received 0 (control), $1.0,2.0$ or $3.0 \mathrm{~kg}$ of soybean hulls in supplements providing $440 \mathrm{~g}$ of protein/d (cottonseed meal used to equalize protein intake) to determine the effect of digestible fiber supplementation on intake and utilization of low-quality native grass hay. Cattle were housed in individual pens and fed coarsely chopped (5-cm screen) native grass hay harvested in mid-November ( $4.1 \%$ crude protein, $54.4 \%$ acid detergent fiber). Digestibilities of hay organic matter, neutral detergent fiber and cellulose were not affected (P>.08) by level of soybean hull supplementation. Total organic matter digestibility increased linearly $(P<.01)$ with added increments of soybean hulls $(45.8 \%, 46.2 \%, 46.6 \%$, $48.6 \%$ for 0 through $3.0 \mathrm{~kg}$ soybean hulls/d, respectively). Hay organic matter intake peaked (quadratic, $P<.05$ ) with 1.0
\end{abstract}


$\mathrm{kg}$ of soybean hulls $(10.1 \mathrm{~kg} / \mathrm{d})$ and decreased when $2 \mathrm{~kg}(9.8$ $\mathrm{kg} / \mathrm{d})$ and $3 \mathrm{~kg}(9.0 \mathrm{~kg} / \mathrm{d})$ of soybean hulls were fed. Although hay intake decreased with added soybean hulls, feeding $3.0 \mathrm{~kg}$ soybean hulls decreased hay organic matter intake by only $.62 \mathrm{~kg}$ compared to the control $(0 \mathrm{~kg}$ soybean hulls). Consequently, digestible organic matter intake increased linearly $(P<.0001)$ with added increments of soybean hulls. Particulate passage rate (Yb-labeled hay) peaked with $1 \mathrm{~kg} / \mathrm{d}$ of supplemental soybean hulls. Ruminal ammonia concentrations tended to be greater for $3 \mathrm{~kg}$ soybean hulls at $2 \mathrm{~h}$ postfeeding. Soybean hulls are a digestible fiber energy supplement that increase total energy intake because of the low substitution rate of hay for soybean hulls. Thus, soybean hulls may provide a useful substitute for cereal grains in high-energy supplements for cattle maintained on low-quality forage.

(Key Words: Soybean Hulls, Supplement, Grass, Beef Cattle.)

\section{Introduction}

Beef cows wintered on dormant native range require protein supplementation because of the low protein content ( $<5 \% \mathrm{CP}$ ) of standing forage (Hobbs et al., 1945; Nelson et al., 1952; Fontenot et al., 1953). Energy supplementation may be required when forage quality or availability are low or energy requirements increase because of environmental or physiological influences. High-energy supplements frequently contain cereal grains that are high in starch and 
may decrease forage digestibility and intake to the extent that the nutritional status of beef cows is not improved (Burroughs et al., 1949b; Campling and Murdoch, 1966; Campbell et al., 1969; Chase and Hibberd, 1987; Trautman, 1987 ) .

Soybean hulls (soyhulls, soybean millrun, soybran flakes), a byproduct of the soybean milling industry, offer an economical, low-starch alternative to cereal grains. Trautman (1987) reported that soybean hulls could effectively replace corn in range supplements for low crude protein ( $4.5 \%$ ) range forage. The effect of soybean hulls on intake and utilization of low-quality forages is unclear. The objective of this study was to evaluate the effect of feeding graded levels of soybean hull supplements on ruminal fermentation and intake and digestibility of low-quality native grass hay by beef cows.

\section{Materials and Methods}

Twelve mature, Hereford cows (average weight, $453 \mathrm{~kg}$ ) and four ruminally-cannulated Hereford X Angus heifers (average weight, $393 \mathrm{~kg}$ ) were blocked according to weight into four groups which were utilized in four simultaneous 4 x 4 latin squares. Four supplements providing $0,1.0,2.0$ or $3.0 \mathrm{~kg}$ of soybean hulls were fed at 0800 each day (table II). Supplemental crude protein (CP) intake was equalized with cottonseed meal. Supplements were formulated 
TABLE II. COMPOSITION AND NUTRIENT INTAKE OF SUPPLEMENTS (DRY MATTER BASIS)

\begin{tabular}{|c|c|c|c|c|}
\hline \multirow[b]{2}{*}{ Item } & \multicolumn{4}{|c|}{ Soybean Hulls, $\mathrm{kg} / \mathrm{d}$} \\
\hline & $\underline{0}$ & 1 & 2 & 3 \\
\hline \multicolumn{5}{|l|}{ Feed composition, 8} \\
\hline Cottonseed meal & 88.70 & 35.12 & 12.46 & \\
\hline Soybean hulls & & 58.17 & 82.76 & 96.26 \\
\hline Dicalcium phosphate & 6.02 & 3.58 & 2.56 & 1.99 \\
\hline Potassium chloride & 1.50 & .89 & .63 & .49 \\
\hline Sodium sulfate, anhydrous & 1.69 & 1.01 & .72 & .56 \\
\hline Trace mineralized salta & 2.04 & 1.21 & .86 & .67 \\
\hline Vitamin A $(30,000 \mathrm{IU} / \mathrm{g})$ & .05 & .03 & .02 & .02 \\
\hline \multicolumn{5}{|l|}{ Intake, $g / d$} \\
\hline Total & 1.076 & 1,814 & 2,553 & 3,291 \\
\hline Crude protein & 424 & 434 & 443 & 453 \\
\hline Total digestible nutrientsb & 725 & 1,159 & 1,594 & 2,028 \\
\hline
\end{tabular}

a Trace mineralized salt contained $928 \mathrm{NaCl}, .258 \mathrm{Mn}, .208 \mathrm{Fe}, .0338 \mathrm{Cu}$, $.038 \mathrm{~S}, .0078 \mathrm{I}, .0058 \mathrm{zn}$ and $.00258 \mathrm{Co}$.

bestimated from NRC (1984). 
(including estimated contribution from native grass hay) to provide $.81 \mathrm{~kg} \mathrm{CP} / \mathrm{d}$ which is in excess of the crude protein requirement for a $400-\mathrm{kg}$ cow, last third of gestation (NRC, 1984). Low-quality native grass hay (4.1\% CP) was harvested in mid-November, coarsely chopped (5-cm screen) and fed fresh each day. Hay, offered and refused, was weighed daily with fresh hay (amount consumed the previous day plus 2.3 $\mathrm{kg})$ placed in the feed bunk after supplement consumption. Cattle were housed separately in covered, concrete-slatted pens $(4.7 \times 2.3 \mathrm{~m})$ with access to fresh water.

Fourteen-day experimental periods consisted of $9 \mathrm{~d}$ of adaptation followed by fecal sampling ( $450 \mathrm{~g}$, as-is) on d 10 through 13 at 0800 and $2000 \mathrm{~h}$. Fecal samples were composited by animal for each period and dried (55 C). Samples of supplement, hay and hay refusals (10\%) were obtained on d 9 through 12 (0800). Supplement and hay samples were composited by period while hay refusals were composited by animal within each period. All samples were ground through a $1-\mathrm{mm}$ screen and stored $(-15 \mathrm{C})$ prior to laboratory analyses. Analyses (table III) included dry matter (DM), crude protein (CP; $N$ X 6.25), and ash (AOAC, 1975 ); neutral detergent fiber (NDF), a sequential acid detergent fiber ( $A D F)$ and permanganate lignin (PI) procedure (Goering and Van Soest, 1970); and acid-insoluble ash (AIA) using the $2 \mathrm{~N} \mathrm{HCl}$ method (Van Keulen and Young, 1977). Hemicellulose was calculated as NDF minus ADF and cellulose 
TABLE III. CHEMICAL COMPOSITION OF GRASS HAY AND SOYBEAN HULL SUPPLEMENTS (DRY MATTER BASIS)

\begin{tabular}{|c|c|c|c|c|c|c|}
\hline \multirow[b]{2}{*}{ Item, \% } & \multicolumn{4}{|c|}{ Soybean Hulls, $\mathrm{kg} / \mathrm{d}$} & \multirow[b]{2}{*}{3} & \multirow[b]{2}{*}{$\mathrm{SEM}^{\mathrm{a}}$} \\
\hline & Hay & 0 & 1 & 2 & & \\
\hline Crude protein & 4.08 & 40.06 & 24.63 & 18.84 & 15.96 & .494 \\
\hline Ash & 7.84 & 17.34 & 12.10 & 11.17 & 10.19 & .405 \\
\hline Acid insoluble ash & 5.46 & .28 & .47 & .78 & .87 & .034 \\
\hline Neutral detergent fiber & 76.91 & 30.30 & 47.79 & 55.65 & 59.37 & .676 \\
\hline Hemicellulose & 22.46 & 10.00 & 15.38 & 14.73 & 15.82 & .536 \\
\hline Acid detergent fiber & 54.45 & 20.29 & 32.40 & 40.91 & 43.55 & .381 \\
\hline Cellulose & 36.93 & 15.12 & 27.54 & 35.74 & 38.33 & .413 \\
\hline Lignin & 12.17 & 5.17 & 4.70 & 4.60 & 4.48 & .220 \\
\hline
\end{tabular}

astandard error of the mean, 4 observations/mean. 
as ADF minus PI minus ADF-ash. Protein characteristics of representative hay, soybean hull, and cottonseed meal samples were estimated with pepsin-insoluble protein (Goering and Van Soest, 1970) and NaCl-soluble protein (Waldo and Goering, 1979). Acid-insoluble ash was used as an indigestible marker to determine digestibility and fecal output. Hay organic matter (OM) digestibility was estimated by dividing hay $O M$ intake into the residual of total OM output minus indigestible supplement OM. Supplement OM digestibility was assumed to equal TDN values (NRC, 1984) for cottonseed meal ( $76 \%$ ) and soybean hulls (64\%).

Particulate passage rate was determined by dosing $250 \mathrm{~g}$ of ytterbium-labeled native grass hay (.68\% Yb) prepared by immersion (Teeter et al., 1984). Labeled hay was dosed at 0800 on $d 9$ and fecal grab samples ( $300 \mathrm{~g}$, as-is) were taken simultaneously with fecal AIA samples at $0,36,48,60,72$ and $96 \mathrm{~h}$ postdosing. Feces collected for AIA determination were composited across time for each animal in each period (16 AIA samples per period). Feces for AIA and Yb analysis were dried ( $55 \mathrm{C}$ ) and ground through a $1-\mathrm{mm}$ screen prior to analysis. Ytterbium was extracted with EDTA (37.2 g EDTA/1, $1 \mathrm{~g} \mathrm{KCl} / \mathrm{l}$ ) and analyzed by atomic-absorption spectrophotometry using a nitrous oxide-acetylene flame (Hart and Polan, 1984). Zero-h samples were composited by period and extractëd with EDTA for preparation of standards. 
Particulate passage rate was estimated from the slope of the regression of the natural logarithm of $\mathrm{Yb}$ concentration over time.

Ruminally-cannulated heifers received an intraruminal dose of $500 \mathrm{ml}$ of Co-EDTA $(1.1 \mathrm{~g} \mathrm{Co})$ at 0800 on $\mathrm{d} 13$ (Uden et al., 1980). Ruminal fluid samples were collected from cannulated heifers at $0,2,4,6,9,12$ and $24 \mathrm{~h}$ postdosing. Ruminal $\mathrm{pH}$ was measured immediately using a combination electrode. A 250-ml aliquot of ruminal fluid was strained through cheesecloth, acidified $(1 \mathrm{ml} 20 \%$ $\mathrm{H}_{2} \mathrm{SO}_{4} / 50 \mathrm{ml}$ ruminal fluid) and frozen $(-15 \mathrm{C})$. Just prior to analysis, ruminal samples were thawed to room temperature and centrifuged at $10,000 \mathrm{x} \mathrm{g}$ for $15 \mathrm{~min}$. The supernatant fraction was then used for ammonia, cobalt and VFA analysis. Ruminal ammonia concentrations were determined with the phenol-hypochlorite procedure described by Broderick and Kang (1980). Cobalt concentrations were analyzed by atomicabsorption spectrophotometry with an air-acetylene flame. Ruminal liquid dilution rate was estimated from the regression of the natural logarithum of Co concentration against time. Ruminal liquid volume was calculated as the marker dose divided by the extrapolated zero time co concentration.

Volatile fatty acid concentrations were determined on ruminal samples centrifuged again at $10,000 \mathrm{x} \mathrm{g}$ for $10 \mathrm{~min}$ and composited across time for each heifer (16 composites: 1 
per heifer for 4 periods). Composite samples were subsampled ( $5 \mathrm{ml}$ ) and combined with $1 \mathrm{ml}$ of $25 \%$ metaphosphoric acid containing 2-ethylbutyric acid (internal standard) and centrifuged at $25,000 \mathrm{x} \mathrm{g}$ for $20 \mathrm{~min}$. Supernate $(2 \mu l)$ was analyzed by standard gas chromotography techniques for volatile fatty acid concentrations (Erwin et al., 1961).

Data were subjected to least squares analysis with square, period, animal (square), treatment, square X period and square $X$ treatment included in the model. Response to soybean hull supplementation was evaluated using orthogonal contrasts for linear, quadratic and cubic trends (Steel and Torrie, 1980).

\section{Results and Discussion}

A larger proportion of soybean hull protein (22.4\%) was soluble in $\mathrm{NaCl}$ than cottonseed meal protein $(16.4 \%$, table IV). The sodium chloride soluble protein content for soybean hulls and cottonseed meal obtained in this study agrees with the values for cottonseed meal (15.3\%) reported by Waldo and Goering (1970). Pepsin indigestible protein content suggests that total tract digestibility of soybean hull protein may be lower than cottonseed meal protein. The proportion of pepsin indigestible protein in the native grass hay was $88.3 \%$, suggesting that the crude protein in low-quality native grass hay is largely unavailable. 
TABLE IV. PROTEIN CHARACTERISTICS OF FEED COMPONENTS

\begin{tabular}{|c|c|c|c|c|}
\hline Item & Hay & $\begin{array}{c}\text { Cottonseed } \\
\text { meal }\end{array}$ & $\begin{array}{c}\text { Soybean } \\
\text { hulls }\end{array}$ & SEMa \\
\hline Crude protein, \% & 4.08 & 44.40 & 14.30 & .494 \\
\hline \multicolumn{5}{|l|}{ NaCl-soluble protein } \\
\hline$\%$ of dry matter & 1.06 & 7.27 & 3.20 & .472 \\
\hline$\%$ of crude protein & 26.0 & 16.4 & 22.4 & 2.02 \\
\hline \multicolumn{5}{|c|}{ Pepsin indigestible protein } \\
\hline$\%$ of dry matter & 3.60 & 9.48 & 4.47 & .038 \\
\hline$\%$ of crude protein & 88.3 & 21.4 & 31.3 & .19 \\
\hline
\end{tabular}

astandard error of the mean, 2 observations/mean. 
TABLE V. DIGESTIBILITY OF LOW-QUALITY GRASS HAY-SOYBEAN HULL DIETS FED TO BEEF COWS

\begin{tabular}{|c|c|c|c|c|c|c|c|c|}
\hline \multirow[b]{2}{*}{ Item } & \multicolumn{4}{|c|}{ Soybean Hulls, $\mathrm{kg} / \mathrm{d}$} & \multirow[b]{2}{*}{ SEM ${ }^{b}$} & \multicolumn{3}{|c|}{ Probability ${ }^{a}$} \\
\hline & 0 & 1 & 2 & 3 & & Lin & Quad & Cub \\
\hline Total organic matter & 45.8 & 46.2 & 46.6 & 48.6 & .70 & .01 & .25 & .67 \\
\hline Hay organic matter & 43.1 & 42.8 & 42.4 & 43.8 & .83 & .64 & .31 & .68 \\
\hline Neutral detergent fiber & 47.7 & 46.8 & 46.7 & 48.1 & .76 & .72 & .15 & .81 \\
\hline Acid detergent fiber & 41.6 & 41.4 & 42.0 & 44.1 & .78 & .03 & .17 & .84 \\
\hline Hemicellulose & 62.0 & 59.5 & 58.1 & 58.1 & 1.00 & .007 & .23 & .92 \\
\hline Cellulose & 57.2 & 55.9 & 57.0 & 58.8 & .80 & .12 & .08 & .65 \\
\hline Apparent crude protein & 37.5 & 35.2 & 32.1 & 34.0 & .93 & .003 & .04 & .18 \\
\hline
\end{tabular}

a Probability represents orthogonal contrasts for linear (Lin), quadratic (Quad) and cubic (Cub) treatment responses.

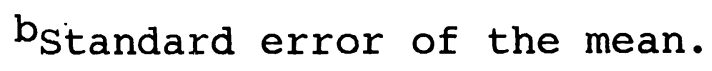


Total OM digestibility (table V) increased linearly $(P<.01)$ with added soybean hulls. This response would be expected due to the increased proportion of digestible soybean hulls in the diet. Soybean hull supplementation did not alter digestibility of hay OM or NDF. Thus, soybean hulls provide a digestible fiber energy supplement that does not interfere with the cellulolytic activity of ruminal microorganisms. In contrast, traditional corn supplements decrease the fiber digestibility of grass hay (Chase and Hibberd, 1987; Highfill et al., 1987).

Acid detergent fiber digestibility increased linearly $(P<.05)$ with increasing levels of soybean hull supplementation (table V). Much of this response may be due to the increased proportion of low lignin, digestible fiber in the diet from soybean hulls. Cellulose digestibility decreased with $1 \mathrm{~kg} / \mathrm{d}$ soybean hulls (quadratic, $\mathrm{P}<.08$ ) but increased with higher levels. In contrast, hemicellulose digestibility decreased linearly $(P<.007)$ with increased soybean hulls.

Apparent crude protein digestibility decreased (quadratic, $\mathrm{P}<.04$ ) with added levels of soybean hulls (table V). Soybean hulls contained more pepsin indigestible protein than cottonseed meal (table IV) which could decrease apparent crude protein digestibility. Alternatively, increased total OM intake with soybean hull supplementation 
TABLE VI. EFFECT OF SOYBEAN HULL SUPPLEMENTATION ON INTAKE OF DIETARY CONSTITUENTS BY BEEF COWS FED LOW-QUALITY GRASS HAY

\begin{tabular}{|c|c|c|c|c|c|c|c|c|}
\hline \multirow[b]{2}{*}{ Item } & \multicolumn{4}{|c|}{ Soybean Hulls, kg/d } & \multirow[b]{2}{*}{$\mathrm{SEM}^{\mathrm{b}}$} & \multicolumn{3}{|c|}{ Probability ${ }^{a}$} \\
\hline & 0 & 1 & 2 & 3 & & Lin & Quad & Cub \\
\hline \multicolumn{9}{|l|}{ Organic matter intake } \\
\hline Hay, kg/d & 9.71 & 10.14 & 9.83 & 9.07 & 2.75 & .09 & .05 & .83 \\
\hline Hay, $\%$ body weight & 2.21 & 2.30 & 2.25 & 2.07 & .061 & .09 & .04 & .95 \\
\hline Hay, g/kg body weight.75 & 101.2 & 105.4 & 102.7 & 94.5 & 2.81 & .09 & .04 & .91 \\
\hline Total, kg/d & 10.59 & 11.67 & 11.99 & 11.88 & .275 & .003 & .04 & .79 \\
\hline Digestible, kg/d & 4.83 & 5.35 & 5.58 & 5.76 & .119 & .0001 & .18 & .66 \\
\hline Crude protein intake, g/d & 821 & 851 & 869 & 876 & 12.8 & .004 & .38 & .97 \\
\hline Fecal dry matter, $\%$ & 22.0 & 21.7 & 21.2 & 20.3 & .48 & .02 & .58 & .97 \\
\hline
\end{tabular}

aprobability represents orthogonal contrasts for linear (Lin), quadratic (Quad) and cubic ( $\mathrm{Cub}$ ) treatment responses.

$\mathrm{b}_{\text {Standard error of the mean. }}$ 
(Table VI) could speed passage rate and decrease apparent crude protein digestibility (Van Soest, 1982).

Hay OM intake peaked (quadratic, $P<.05$ ) with $1 \mathrm{~kg}$ of soybean hull supplementation and declined thereafter (table VI). Soybean hulls swell very rapidly when exposed to water and could decrease hay intake via ruminal fill. Compared to the control (0 kg soybean hulls), however, hay OM intake decreased only $.64 \mathrm{~kg} / \mathrm{d}$ when $3 \mathrm{~kg}$ of soybean hulls were fed indicating that ruminal fill from soybean hulls was not a major factor limiting hay intake. The substitution rate observed with soybean hull supplementation $(.64 \mathrm{~kg}$ hay $/ 3 \mathrm{~kg}$ soybean hulls) is extremely low compared to the $3.7 \mathrm{~kg}$ decrease in hay intake observed with $3 \mathrm{~kg}$ corn supplement (Chase and Hibberd, 1987).

Total OM intake (hay plus supplement) peaked (quadratic, $\mathrm{P}<.04$ ) with $2 \mathrm{~kg} / \mathrm{d}$ of soybean hull supplementation (table VI). At $3 \mathrm{~kg} / \mathrm{d}$ of soybean hulls, however, total OM intake was still higher than with 0 or 1 $\mathrm{kg} / \mathrm{d}$ of soybean hulls. Because changes in OM digestibility were small, changes in OM intake in this study may be more closely related to rate of digesta passage.

Fecal dry matter content decreased linearly ( $P<.02)$ with increased quantities of soybean hulls (table VI). Bran feeds have a mild laxative effect for livestock (Morrison, 1959). Decreased fecal dry matter content with increased 
soybean hull supplementation suggests a mild laxative effect even at the low levels of supplementation used in this study •

Digestible OM intake increased linearly $(P<.0001)$ with added soybean hulls (table VI). This response would be expected because hay $\mathrm{OM}$ intake decreased only slightly as the quantity of highly digestible soybean hulls increased to $3 \mathrm{~kg} / \mathrm{d}$. Increased digestible OM intake suggests that soybean hull supplementation should increase energy intake of cows maintained on low-quality forage. In contrast, Chase and Hibberd (1987) found that corn supplementation (up to $3 \mathrm{~kg} / \mathrm{d}$ ) did not improve digestible oM intake of cows fed low-quality grass hay.

Particulate passage rate, ruminal liquid volume and liquid flow rate peaked with $1 \mathrm{~kg}$ soybean hulls (table VII). This response corresponds with the peak in hay intake (table VI). Liquid dilution rate tended to increase (linear, $\mathrm{P}<.11$ ) and liquid turnover time decreased (linear, $\mathrm{P}<.10$ ) with added soybean hulls.

Ruminal ammonia concentrations tended (quadratic, $\mathrm{P}<.20$ ) to be greater for $3 \mathrm{~kg}$ soybean hulls at $2 \mathrm{~h}$ postfeeding (figure 1). Mean ruminal ammonia concentrations were lowest for $1 \mathrm{~kg}$ soybean hulls and increased (quadratic, $P<.09)$ as additional soybean hulls were fed (table VIII). Ruminal ammonia concentrations declined by $6 \mathrm{~h}$ postfeeding and remained low ( $<1 \mathrm{mg} / \mathrm{dl})$ throughout the day for all but 
TABLE VII. PARTICULATE AND LIQUID KINETICS OF BEEF COWS FED LOW-QUALITY GRASS HAY SUPPLEMENTED WITH SOYBEAN HULLS

\begin{tabular}{|c|c|c|c|c|c|c|c|c|}
\hline \multirow[b]{2}{*}{ Item } & \multicolumn{4}{|c|}{ Soybean Hulls, $\mathrm{kg} / \mathrm{d}$} & \multirow[b]{2}{*}{ SEM $^{\mathrm{b}}$} & \multicolumn{3}{|c|}{ Probabilitya } \\
\hline & 0 & 1 & 2 & 3 & & Lin & Quad & $\mathrm{Cub}$ \\
\hline Particulate passagie rate, $\% / \mathrm{h}$ & 3.28 & 3.81 & 3.71 & 3.59 & .002 & .28 & .08 & .43 \\
\hline Liquid dilution rate, $\frac{\circ}{6} / \mathrm{h}$ & 8.05 & 9.15 & 8.94 & 9.50 & .492 & .11 & .61 & .39 \\
\hline Ruminal liquid volume, L & 90.7 & 97.9 & 92.7 & 86.6 & 5.73 & .53 & .30 & .67 \\
\hline Liquid flow rate, $\mathrm{L} / \mathrm{h}$ & 7.20 & 8.82 & 8.11 & 8.11 & .464 & .38 & .14 & .20 \\
\hline Liguid turnover time, $h$ & 12.77 & 11.01 & 11.28 & 10.66 & .696 & .10 & .45 & .39 \\
\hline
\end{tabular}




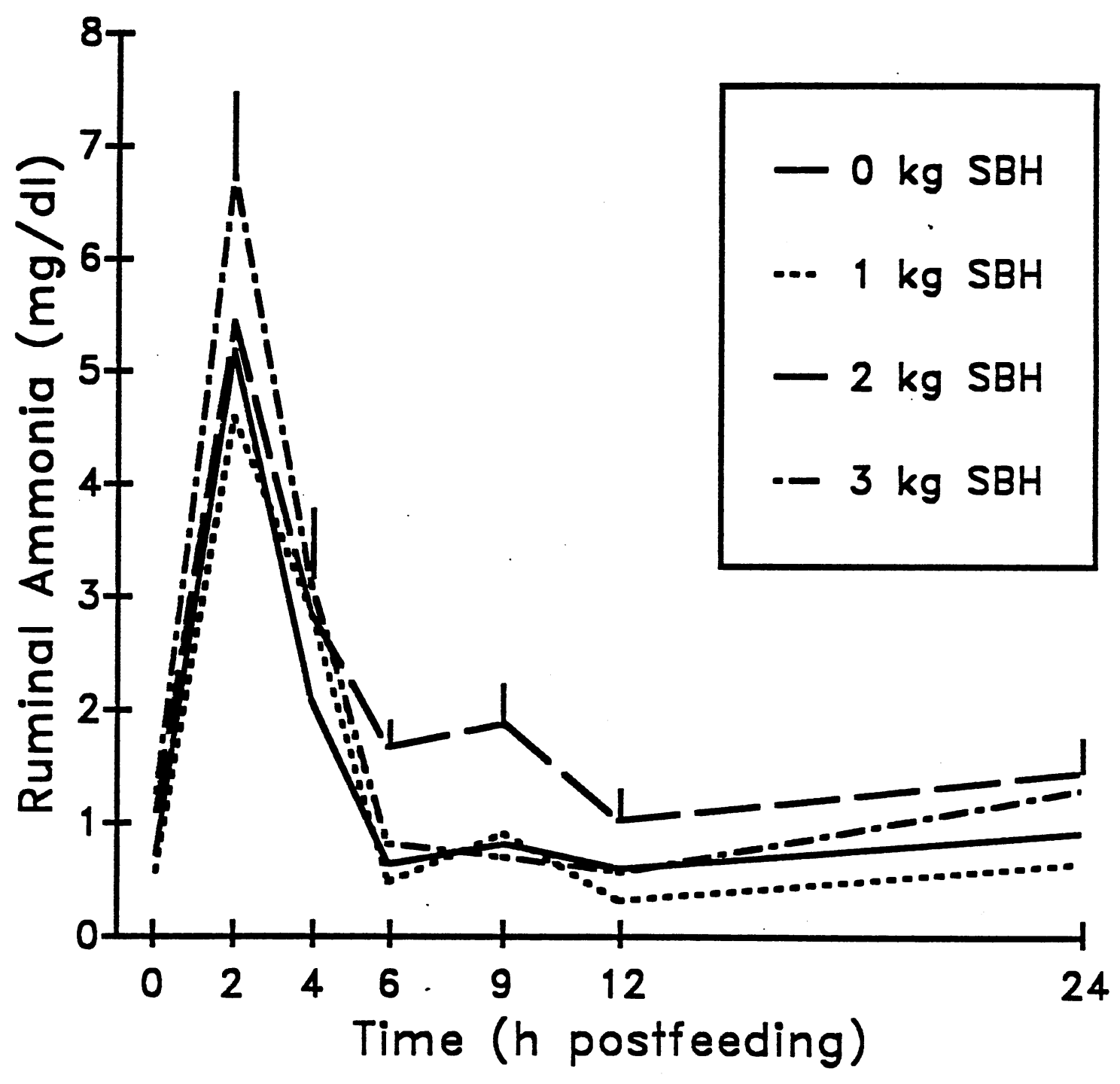

Figure 1. Ruminal Ammonia Concentrations PostSupplementation for Beef Heifers fed Graded Levels of Soybean Hulls 
TABLE VIII. CHARACTERISTICS OF RUMINAL FLUID FROM BEEF HEIFERS MAINTAINED ON LOW-QUALITY GRASS HAY DIETS SUPPLEMENTED WITH SOYBEAN HULLS

\begin{tabular}{|c|c|c|c|c|c|c|c|c|}
\hline \multirow[b]{2}{*}{ Item } & \multicolumn{4}{|c|}{ Soybean Hulls, $\mathrm{kg} / \mathrm{d}$} & \multirow[b]{2}{*}{ SEM $\mathrm{b}$} & \multicolumn{3}{|c|}{ Probability ${ }^{a}$} \\
\hline & 0 & 1 & 2 & 3 & & Lin & Quad & $\mathrm{Cub}$ \\
\hline \multicolumn{9}{|l|}{ Ruminal } \\
\hline $\mathrm{pH}$ & 6.45 & 6.49 & 6.46 & 6.39 & .029 & .21 & .11 & .89 \\
\hline Ammonia, mg/dl & 2.21 & 1.50 & 1.57 & 2.08 & .302 & .82 & .09 & .81 \\
\hline \multicolumn{9}{|l|}{ Volatile Fatty Acids } \\
\hline Total, mM & 63.5 & 65.7 & 74.8 & 74.9 & 3.75 & .05 & .79 & .39 \\
\hline Acetate, mol $/ 100 \mathrm{~mol}$ & 78.52 & 77.72 & 76.18 & 76.05 & .474 & .006 & .50 & .35 \\
\hline Propionate, mol/100 mol & 14.64 & 14.94 & 15.84 & 15.73 & .222 & .006 & .40 & .16 \\
\hline Butyrate, mol/100 mol & 6.24 & 6.68 & 6.75 & 6.96 & .254 & .10 & .66 & .67 \\
\hline Valerate, mol $/ 100 \mathrm{~mol}$ & .58 & .58 & .67 & .64 & .028 & .09 & .71 & .13 \\
\hline Acetate: Propionate & 5.37 & 5.22 & 4.81 & 4.85 & .100 & .005 & .38 & .18 \\
\hline
\end{tabular}

aprobability represents orthogonal contrasts for linear (Lin), quadratic (Quad) and cubic ( $\mathrm{Cub}$ ) treatment responses.

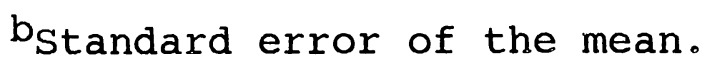


the control ( $0 \mathrm{~kg}$ soybean hulls). Ruminal ammonia concentrations for the control (950 g cottonseed meal) were higher than soybean hull supplements at 6 through $12 \mathrm{~h}$ postsupplementation. Cottonseed meal protein may be degraded slower than soybean hull protein resulting in higher ruminal ammonia concentrations at later sampling times. Alternatively, increased ruminal fermentation with soybean hull supplementation could increase ammonia incorporation into microbial protein and decrease ruminal ammonia concentrations. Chase and Hibberd (1987) also observed decreased ammonia concentrations when corn supplements were fed to beef cows maintained on native grass hay.

Ruminal pH was decreased at 4,6 and $9 \mathrm{~h}$ postfeeding when 2 or $3 \mathrm{~kg}$ of soybean hulls were fed (figure 2). Mean ruminal $\mathrm{pH}$ also decreased (quadratic, $\mathrm{P}<.09$ ) with added soybean hulls (table VIII). Decreased pH suggests that the digestible fiber in soybean hulls may have stimulated ruminal fermentation. With $3 \mathrm{~kg}$ of soybean hulls/d, ruminal $\mathrm{pH}$ decreased to 6.23 at 6 and $9 \mathrm{~h}$ postfeeding. All other $\mathrm{pH}$ values remained within the range $(6.3$ to 7.0$)$ considered optimal for cellulolysis ( $\phi r s k o v, 1982)$.

Total VFA concentrations increased linearly $(P<.05)$ with added increments of soybean hulls (table VIII). Increased total VFA concentrations coupled with decreased ruminal $\mathrm{pH}$ suggests that soybean hulls provide a very 


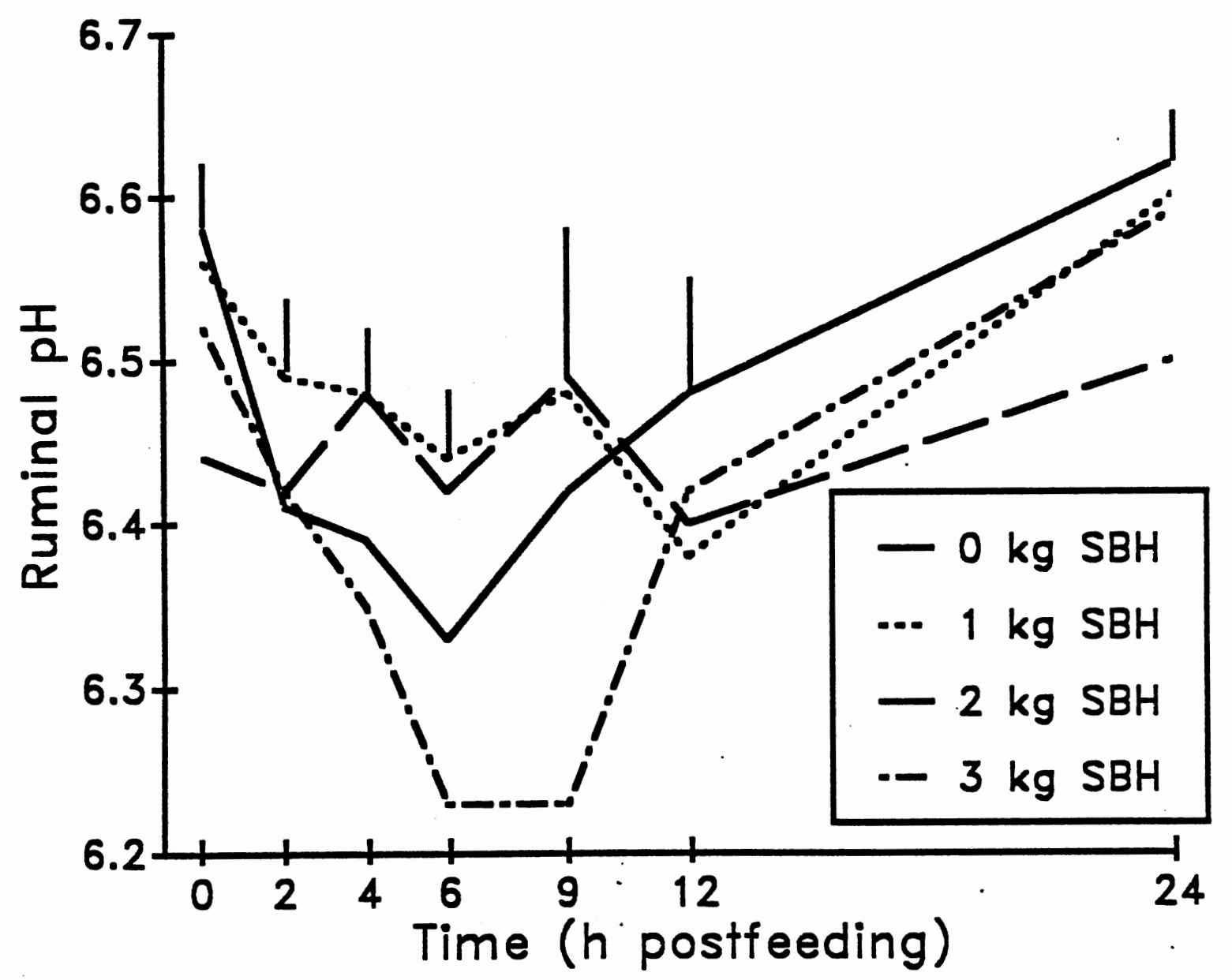

Figure 2. Ruminal pH Post-Supplementation for Beef Heifers fed Graded Levels of Soybean Hulls 
fermentable substrate for ruminal microorganisms. In contrast, Chase and Hibberd (1987) and Branine and Galyean (1985) reported no significant change in VFA concentrations in cattle fed differing levels of $\operatorname{corn}(0,1,2$ or $3 \mathrm{~kg}$ and $0, .5$ or $1 \mathrm{~kg}$, respectively). The molar proportion of acetate decreased (linear, $\mathrm{P}<.01$ ) while propionate increased (linear, $\mathrm{P}<.01$ ) decreasing the acetate:propionate ratio (linearly; $P<.05$ ) with added levels of soybean hull supplementation. Proportions of butyric and valeric acid tended to increase linearly $(P<.10)$ with increasing levels of soybean hulls. Thus, ruminal bacteria of cattle supplemented with soybean hulls supply the host with a greater concentration of VFA that contain a larger proportion of energetically-efficient propionate.

In this study, native grass hay digestibility was not altered by incorporating soybean hulls into the supplement composition suggesting soybean hulls are not digested at the expense of forage. Soybean hulls provide a fibrous substrate that ruminal micro-organisms may recognize and ferment similarly to native grass hay. In this manner, soybean hulls could provide supplemental energy to grazing beef cows without decreasing forage utilization. In contrast, corn supplementation $(0,1,2$, or $3 \mathrm{~kg} / \mathrm{d})$ decreased digestibility of low-quality native grass hay (Chase and Hibberd, 1987). 
Hay intake increased slightly $(430 \mathrm{~g})$ with $1 \mathrm{~kg}$ soybean hulls and then decreased with 2 or $3 \mathrm{~kg}$ of soybean hulls. In contrast to corn supplementation (Chase and Hibberd, 1987), $3 \mathrm{~kg}$ of soybean hulls decreased hay intake only .62 $\mathrm{kg}$ compared to native grass hay fed alone. Soybean hulls fed in small quantities ( $1 \mathrm{~kg} / \mathrm{d}$ ) may supply a fermentable carbohydrate source or other cofactor necessary to stimulate utilization and intake of low-quality grass hay. Total organic matter digestibility and intake increased when soybean hulls were fed suggesting that the energy status of grazing cows should improve when supplemented with soybean hulls.

Although supplementation with soybean hulls had minimal effects on native grass hay intake and digestibility, ruminal fermentation parameters changed significantly. Soybean hull supplementation increased total VFA concentrations and the molar proportion of propionate suggesting improved microbial fermentation with a more energetically efficient product. This response, combined with the increase in digestible organic matter intake should further improve the energy status of beef cows supplemented with soybean hulls.

This study suggests that soybean hulls present an effective alternative to cereal grains such as corn for cattle consuming low-quality native forage. Soybean hulls do not exhibit the negative associative effects associated 
with corn when fed to supplement native grass hay. Any level $(1,2$ or $3 \mathrm{~kg} / \mathrm{d})$ of soybean hull supplementation did not significantly affect hay digestibility, while feeding soybean hulls at $1 \mathrm{~kg} / \mathrm{d}$ optimized hay intake. Consequently, supplements formulated with soybean hulls should effectively supply energy and also maximize utilization of standing forage by beef cows. Soybean hulls should be incorporated into range supplements when economically justified. 
CHAPTER IV

\section{SUMMARY}

oklahoma native rangelands are a valuable commodity to the cow-calf producer. They provide an established source of forage capable of maintaining dry cows during the months of May, June and, depending on weather effects, July as the sole source of protein and energy (Waller et al., 1972; NRC, 1984 ).

As the season progresses, the nutritive quality of native rangeland decreases to the point that supplementation is required to maintain cow performance. The nutrient concentration of range forage becomes so dilute and the cell wall content so great that intake may be limited by the physical capacity of the reticulo-rumen. Alternatively, insufficent or incorrect levels of factors such as available nitrogen and energy may alter microbial fermentation. Forage intake may also be influenced by the physiological status of the cow. Supplementation, therefore, is used to meet the requirements of the cow within the constraints of the previously mentioned factors. 
Traditionally, high-protein sources such as cottonseed meal or soybean meal have been utilized to fill the gap between the protein requirements of the cow and the amount of protein the native rangeland can supply. Additional energy may be required when rangeland forage supply is limited because of snowfall, drought or when beef cattle energy requirements increase due to late gestation, lactation or rebreeding. High-starch cereal grains have been used in combination with high-protein sources to formulate $20 \%$ crude protein feeds for winter supplements. Research has shown (Chase and Hibberd, 1987) that the starch contained in grains such as corn, depresses hay intake and digestibility to a point that the energy status of the cows is not improved. Because of the depression in hay intake and digestibility with highstarch grains, low starch, low lignin (digestible fiber) byproduct feedstuffs such as soybean hulls have received interest.

Previous work has shown that cellulose, crude fiber and protein digestibilities are maintained or improved when soybean hulls are fed as part of the diet (Johnson et al., 1962; Hintz et al., 1964; Bhattacharya and Sleiman, 1977; Sudweeks, 1977). Soybean hulls and corn gluten feed also tend to improve neutral detergent fiber digestibilities (Highfill et al., 1987). Highly digestible fiber sources may not actually be more 
digestible than corn but instead may not possess the negative effects associated with feeding high starch energy feeds such as corn (Chase and Hibberd, 1987).

Fleck et al. (1987) reported comparable performance of cows supplemented with corn gluten feed only or in combination with soybean hulls. Performance of lactating beef cows supplemented with soybean hulls has been equal or better than cows fed traditional energy sources such a corn or oats (Wagner et al., 1965; MacGregor, 1976; Trautman, 1987). Beet pulp has also provided comparable performance when fed to lactating cows in place of barley (Bhattacharya and Sleiman, 1977).

In this study, soybean hulls did not significantly affect hay, neutral detergent fiber or cellulose digestibilities even when fed at $3 \mathrm{~kg} / \mathrm{d}$ suggesting that soybean hulls are not digested at the expense of native grass hay. Hay organic matter intake peaked with $1 \mathrm{~kg}$ of soybean hulls. Even at $3 \mathrm{~kg} / \mathrm{d}$ of soybean hulls, substitution of soybean hulls for hay was low $13 \mathrm{~kg}$ soybean hulls decreased hay organic matter intake $.62 \mathrm{~kg}$ ). Soybean hulls and other digestible fiber energy sources may represent a substrate similar to forages that the microbial population easily incorporates into its fermentation scheme with few, if any, detrimental effects. Feeding soybean hulls increases digestibile organic matter intake of beef cows fed low-quality native grass 
hay. Thus, supplemental soybean hull should effectively improve the energy status of grazing cattle. This study illustrates that soybean hulls can be included as an energy component in supplements for cattle on rangeland as cost permits. 


\section{LITERATURE CITED}

AAFCO. 1981. Official Publication, Association of American Feed Control officials, Inc.

Adams, D.C. and R.J. Kartchner. 1984. Effect of level of forage intake on rumen ammonia, pH, liquid volume and liquid dilution rate in beef cattle. J. Anim. Sci. $58: 708$.

Akin, D.E. 1979. Microscopic evaluation of forage digestion by rumen microorganisms-A review. J. Anim. Sci. $48: 70$.

Akin, D.E. and H.E. Amos. 1975. Rumen bacterial degradation of forage cell walls investigated by electron microscopy. Appl. Microbiol. 29:692.

Alden, D.E. 1975. Soy Processing: From beans to ingredients. J. Am. Oil Chemists' Soc. 52:244.

Allison, C.D. 1985. Factors affecting forage intake by range ruminants: A review. J. Range Manage. 38:305.

Amos, H.E. and J. Evans. 1976. Supplementary protein for low quality bermudagrass diets and microbial protein synthesis. J. Anim. Sci. 43:861.

AOAC. 1975. Official Methods of Analysis (12th Ed.). Association of Official Analytical Chemists, Washington, D.C.

Arelovich, H.M., D.G. Wagner and C.A. Hibberd. 1983. Effect of supplementation program on intake and utilization of low quality prairie hay by steers. Oklahoma Agr. Exp. Sta. MP-114:232.

Barton, K.J. and C.A. Hibberd. 1984. Effects of protein supplementation on ruminal fermentation of low quality native grass hay in steers. Oklahoma Agr. Exp. Sta. Res. Rep. MP-116:165. 
Bath, D.L. 1981. Feed by-products and their utilization by ruminants. In: J.T. Huber (Ed.) Upgrading residues and by-products for animals. CRC Press, Florida.

Bellows, R.A. and 0.0. Thomas. 1976. Some effects of supplemental grain feeding on performance of cows and calves on range forage. J. Range Manage. 29:192.

Bentley, G., G.V. Quicke and A.L. Moxon. 1958. Digestibility and feeding value of soybean hulls. J. Anim. Sci. 17:1193.

Bhattacharya, A.N. and M. Harb. 1973. Dried citrus pulp as a grain replacement for Awasi lambs. J. Anim. Sci. $36: 1175$.

Bhattacharya, A.N. and F.T. Sleiman. 1977. Beet pulp as a grain replacement for dairy cows and sheep. J. Dairy Sci. $54: 89$.

Blaxter, K.L. and R.S. Wilson. 1962. The voluntary intake of roughages by steers. Anim. Prod. $4: 351$.

Branine, M.E. and M.L. Gaylean. 1985. Influence of supplemental grain on forage intake, rate of passage and rumen fermentation in steers grazing summer blue grama rangeland. Proc. West. Sect. Amer. Soc. Anim. Sci. p. 290 .

Brazle, F.K., L.H. Harbers and C.E. Owensby. 1979. Structural inhibitors of big and little bluestem digestion observed by scanning electron microcopy. J. Anim. Sci. 48:1457.

Briggs, H.M., W.D. Gallup, A.E. Darlow and C. Kinney. 1946. Yield and feeding values of prairie hay cut at different stages of maturity. Okla. Agr. Exp. Sta. Bull. 296.

Broderick, G.A. and J.H. Kang. 1980. Automated simultaneous determination of ammonia and total amino acids in ruminal fluid and in vitro media. J. Dairy Sci. 63:64.

Bryant, M.P. 1973. Nutritional requirements of predominant rumen cellulolytic bacteria. Fed. Proc. $32: 1809$.

Burroughs, W. and P. Gerlaugh. 1949. The influence of soybean oil meal upon roughage digestion in cattle. J. Anim. Sci. $8: 3$. 
Burroughs, W., P. Gerlaugh, B.H. Edgington and R.M. Bethke. 1949a. Further observations on the effect of protein upon roughagee digestion in cattle. J. Anim. Sci. $8: 9$.

Burroughs, W., P. Gerlaugh, B.H. Edgington and R.M. Bethke. 1949b. The influence of corn starch upon roughage digestion in cattle. J. Anim. Sci. 8:271.

Campbell, C.M., L.B. Sherrod and S.M. Ishizaki. 1969. Effect of supplemental protein and energy levels on the utilization of kikuyu grass (pennisetum clandestinum). J. Anim. Sci. 29:634.

Campling, R.C. and J.C. Murdoch. 1966. The effect of concentrates on the voluntary intake of roughages by cows. J. Dairy Res. 33:1

Castle, M.E., A.D. Drysdale and J.N. Watson. 1966. The effect of feeding dried sugar-beet pulp on the intake and production of dairy cows. J. Dairy Res. 33:123.

Chase, C.C., Jr. and C. A. Hibberd. 1987. Utilization of low-quality native grass hay by cows fed increasing quantities of corn grain. J. Anim. Sci. 65:557.

Church, D.C. and A. Santos. 1981. Effect of graded levels of soybean meal and of a nonprotein nitrogen-molasses supplement on consumption and digestibility of wheat straw. J. Anim. Sci. 53:1609.

Cochran, R.C., D.C. Adams, P.O. Currie and B.W. Knapp. 1986. Cubed alfalfa hay or cottonseed meal-barley as supplements for beef cows grazing fall-winter range. J. Range Mange. 39:361.

Cook, C.W. and L.E. Harris. 1968. Effect of supplementation on intake and digestibility of range forage. Utah Agr. Exp. Sta. Bull. 475 .

Cordova, F.J., J.D. Wallace and R.D. Pieper. 1978. Forage intake by grazing livestock: A review. J. Range Mange. 31:430.

Crabtree, J.R. and G.I. Williams. 1971. The voluntary intake and utilization of roughage-concentrate diets by sheep 1. Concentrate supplements for hay and straw. Anim. Prod. 13:71.

Crampton, E.W. and L.E. Harris. 1969. Applied Animal Nutrition. 2nd Ed. W.H. Freeman and Company, San Francisco, Ca. 
Cullison, A.E. 1972. Feeds and Feeding. Reston Publishing Co., Inc., Reston, Va.

Davis, D., R.R. Schalles, G.H. Kiracofe and D.L. Good. 1977. Influence of winter nutrition on beef cow reproduction. J. Anim. Sci. 46:430.

DeHaan, K., T. Klopfenstein and R. Stock. 1983. Protein and energy source for ruminants. Nebr. Beef Cattle Rep. MP $-44: 19$.

Elliott, R.C. 1967. Voluntary intake of low-protein diets by ruminants $I$. Intake of food by cattle. J. Agric. Sci. Camb. 69:375.

Elliott, R.C. and J.H. Topps. 1963. Voluntary intake of low protein diets by sheep. Anim. Prod. 5:269.

Ellis, W.C. 1978. Determinants of grazed forage intake and degestibility. J. Dairy Sci. 61:1828.

el-Shazly, K., B.A. Dehority and R.R. Johnson. 1961. Effect of starch on the digestion of cellulose in vitro and in vivo by rumen microorganisms. J. Anim. Sci. $20: 268$.

Erwin, E.S., G.J. Mario, and E.M. Emery. 1961. Volatile fatty acid analysis of blood and rumen fluid by gas chromatography. J. Dairy Sci. 44:1768.

Evans, E. 1981. An evaluation of the relationships between dietary parameters and rumen solid turnover rate. Can. J. Anim. Sci. 61:97.

Faulkner, D.B., L.L. Berger, G.C. Fahey, Jr., R.A. Barclay, and G.F. Cmarik. 1986. Evaluation of high fiber byproducts for growing steers. Illinios Beef Cattle Rep., p 44.

Fick, K.R., C.B. Ammerman, C.H. McGowan, P.E. Loggins and J.A. Cornell. 1973. Influence of supplemental energy and biuret nitrogen on the utilization of low quality roughage by sheep. J. Anim. Sci. 36:137.

Fleck, A.T. 1987. The value of corn gluten feed as a source of supplemental protein and energy for grazing beef cattle. M.S. Thesis. Okla. State Univ., Stillwater, OK.

Fleck, A.T., K.S. Lusby and F.T. McCollum. 1987. The value of corn gluten feed as a supplement for beef cattle grazing native range. ARPAS $3: 1$. 
Fontenot, J.P., W.D. Gallup and A.B. Nelson. 1953. Metabolism studies with steers fed 20-, 30-, and 40percent protein supplements. Okla. Agr. Exp. Sta. Misc. Pub. 31:23.

Furr, R.D. and A.B. Nelson. 1964. Effect of level of supplemental winter feed on calf weight and on milk production of fall-calving range beef cows. J. Anim. Sci. $23: 775$.

Gallup, W.D. and H.M. Briggs. 1948. The apparent digestibility of prairie hay of variable protein content, with some observations of fecal nitrogen excretion by steers in relation to their dry matter intake. J. Anim. Sci. 7:110.

Ganev, G., E.R. Ørskov and R. Smart. 1979. The effect of roughage or concentrate feeding and rumen retention time on total degradation of protein in the rumen. $\mathrm{J}$. Agric. Sci. (Camb.) 93:651.

Goering, H.K. and P.J. Van Soest. 1970. Forage fiber analyses (apparatus, reagents, procedures, and some application). Agricultural Handbook No.379, USDA, ARS.

Gonzalez, J.M. 1987. Digestive and metabolic changes in fall-calving beef cows due to stage of production and early postpartum protein supplementation. M.S. Thesis Okla. State Univ., Stillwater, OK.

Green, D., R. Stock and T. Klopfenstein. 1987. Corn gluten feed-A review. Nebr. Beef Cattle Rep. MP$52: 16$.

Grovum, W.I. 1987. A new look at what is controlling food intake. In: F.N. Owens (ed.) Feed Intake by Beef Cattle. Oklahoma Agr. Exp. Sta. MP 121:1.

Guthrie, M.J., D.G. Wagner and D.S. Buchanan. 1984a. Effect of level of protein supplementation on intake and utilization of medium quality prairie hay by heifers. Oklahoma Agr. Expt. Sta. MP-116:156.

Guthrie, M.J., D.G. Wagner and D.C. Weakley. $1984 \mathrm{~b}$. Effect of supplemental protein or grain on intake and utilization of medium quality prairie hay by steers. Oklahoma Agr. Exp. Sta. MP-116:160. 
Hart, S.P. and C.E. Polan. 1984. Simultaneous extraction and determination of ytterbium and cobalt ethylenediaminetetraacetate complex in feces. J. Dairy Sci. 67:888.

Hayes, D.C. 1985. Seasonal nitrogen translocation in big bluestem during drought conditions. J. Range Mange. $38: 406$.

Hennessy, D.W., P.J. Williamson, J.V. Nolan, T.J. Kempton and R.A. Leng. 1983. The roles of energy- or protein-rich supplements in the subtropics for young cattle consuming basal diets that are low in digestible energy and protein. J. Agric. Sci., Camb. $100: 657$.

Henning, P.A., Yvonne Van Der Linden, M.E. Mattheyse, W.K. Nauhaus, H.M. Schwartz and F.M.C. Gilchrist. 1980. Factors affecting the intake and digestion of roughage by sheep fed maize straw supplemented with maize grain. J. Agric. Sci. Camb. $94: 565$.

Hibberd, C.A., C.C. Chase and C. Worthington. 1986. Corn vs soybean hull supplements for fall-calving beef cows in winter. Okla. Agr. Exp. Sta. Res. Rep. MP-118:192.

Highfill, B.D., D.I. Boggs, H.E. Amos and J.G. Crickman. 1987. Effects of high fiber energy supplements on fermentation characteristics and in vivo and in situ digestibilities of low quality fescue hay. J. Anim. Sci. $65: 224$.

Hintz, H.F., M.M. Mathias, H.F. Ley, Jr. and J.K. Loosli. 1964. Effects of processing and of feeding hay on the digestibility of soybean hulls. J. Anim. Sci. 23:43.

Hobbs, C.S., W.D. Gallup and B.R. Taylor. 1945. The composition and apparent digestibility of bluestem grass in the growing stage, and in the dry and hay stages when supplemented with cottonseed cake. J. Anim. Sci. 4:395.

Horn, G.W. and F.T. McCollum. 1987. Energy supplementation of grazing ruminants. Proc. Grazing Livestock Nutrition Conference. Journal Article 2393. Okla. Agr. Exp. Sta. Stillwater. 
Hsu, J.T., D.B. Faulkner, K.A. Garleb, R.A. Barclay, G.C. Fahey, Jr. and L.I. Berger. 1987. Evaluation of corn fiber, cottonseed hulls, oat hulls and soybean hulls as roughage sources for ruminants. J. Anim. Sci. $65: 244$.

Hughes, J.H., D.F. Stephens, K.S. Lusby, L.S. Pope, J.V. Whiteman, L.J. Smithson and R. Totusek. 1978a. Longterm effects of winter supplement on growth and development of hereford range females. J. Anim. Sci. $47: 805$.

Hughes, J.H., D.F. Stephens, K.S. Lusby, L.S. Pope, J.V. Whiteman, L.J. Smithson and R. Totusek. 1978. Longterm effects of winter supplement on the productivity of range cows. J. Anim. Sci. 47:816.

Ingalls, J.R., J.W. Thomas, M.B. Tesar and D.L. Carpenter. 1966. Relations between ad libitum intake of several forage species and gut fill. J. Anim. Sci. 25:283.

Johnson, R.R., E.W. Klosterman and H.W. Scott. 1962 . Studies on the feeding value of soybran flakes for ruminants. J. Anim. Sci. 21:406.

Jordan, W.A., E.E. Lister, J.M. Wauthy and J.E. Comeau. 1973. Voluntary roughage intake by nonpregnant and pregnant or lactating beef cows. Can. J. Anim. Sci. $53: 733$.

Judkins, M.B., L.J. Krysl, J.D. Wallace, M.I. Galyean, K.D. Jones and E.E. Parker. 1985. Intake and diet selection by protein supplemented grazing steers. J. Range Manage. 38:210.

Kane, E.A., W.C. Jacobson and P.M. Damewood, Jr. 1959. Effect of corn starch on digestibility of alfalfa hay. J. Dairy Sci. 42:849.

Kartchner, R.J. 1981. Effects of protein and energy supplementation of cows grazing native winter range forage on intake and digestibility. J. Anim. Sci. $51: 432$.

Kirk, W.G. and G.K. Davis. 1954. Citrus products for beef cattle. Fla. Agr. Exp. Sta. Bull. 538 .

Knox, J.H. and W.E. Watkins. 1958. Supplements for range cows. New Mexico Agr. Exp. Sta. Bull. 425. 
Kronberg, S.I., K.M. Havstad, E.I. Ayers and D.E. Doornbos. 1986. Influence of breed on forage intake of range beef cows. J. Range Manage. 39:421.

Lamb, C.S. and J. Eadie. 1979. The effect of barley supplements on the voluntary intake and digestion of low quality roughages by sheep. J. Agric. Sci. Camb. $92: 235$.

Lantow, J.I. 1932. The comparative values of cottonseed cake and ground yellow corn for the supplemental feeding of cows and weaned calves on the range. New Mexico Agr. Exp. Sta. Bull. 202.

Loy, D.D. 1986. Feeding corn processing by-products to beef cattle. Proc. Cornbelt Cow-calf conference, Iowa.

Lusby, K.S., D.F. Stephens, L. Knori and R. Totusek. 1976a. Effects of winter supplement level on roughage intake and digestibility of three breeds of cows in drylot. Okla. Agr. Exp. Sta. Res. Rep. MP-96:19.

Lusby, K.S., D.F. Stephens and R. Totusek. 1976b. Influence of breed and level of winter supplement on forage intake of range cows. J. Anim. Sci. 43:543.

Lyons, T., P.J. Caffrey and W.J. O'Connell. 1970. The effect of energy, protein and vitamin supplementation on the performance and voluntary intake of barley straw by cattle. Anim. Prod. 12:323.

MacGregor, C.A., F.G. Owen and L.D. McGill. 1976. Effect of increasing ration fiber with soybean mill run on digestibility and lactation performance. J. Dairy Sci. $59: 682$.

MCCollum, F.T. and M.L. Galyean. 1985a. Cattle grazing blue grama rangeland II. Seasonal forage intake and digesta kinetics. J. Range Manage. 38:543.

McCollum, F.T. and M.I. Galyean. 1985b. Influence of cottonseed meal supplementation on voluntary intake, rumen fermentation and rate of passage of prairie hay in beef steers. J. Anim. Sci. 60:570.

McCollum, F.T., M.L. Galyean, L.J. Krysl and J.D. Wallace. 1985. Cattle grazing blue grama rangeland. I. Seasonal diets and rumen fermentation. J. Range Mange. $38: 539$. 
McDonnel1, M.L., T.J. Klopfenstein and J.K. Merrill. 1982. Soybean hulls as energy source for ruminants. Nebr. Beef Cattle Rep. 43:54.

Merrill, J. and T. Klopfenstein. 1984. Soybean hulls for grazing beef cattle. Nebr. Beef Cattle Rep. 47:41.

Merrill, J. and T. Klopfenstein. 1985. Soyhull utilization in forage diets. Nebr. Beef Cattle Rep. $48: 48$.

Mertens, D.R. and J.R. Loften. 1980. The effect of starch on forage fiber digestion kinetics in vitro. J. Dairy Sci. $63: 1437$.

Meyer, M.W. and R.D. Brown. 1985. Seasonal trends in the chemical composition of ten range plants in south Texas. J. Range Mange. 38:154.

Morrison, F.B. 1959. Feed and Feeding. 22nd Ed. Morrison Publishing Co., Clinton, IA.

Mould, F.I. and E.R. Ørskov. 1983. Manipulation of rumen fluid $\mathrm{pH}$ and its influence on cellulolysis in sacco, dry matter degradation and the rumen microflora of sheep offered either hay or concentrate. Anim. Feed. Sci. and Tech. 10:1.

Nelson, A.B., A.E. Darlow, R.W. MacVicar and W.D. Campbell. 1952. The relative value of alfalfa hay and cottonseed cake for winter feed in a commercial cow herd. Okla. Agr. Exp. Sta. Misc. Pub. MP-27:29.

Nocek, J.E. and M.B. Hall. 1984. Characterization of soyhull fiber digestion by in situ and in vitro enzymatic procedures. J. Dairy Sci. 67:2599.

NRC. 1984. Nutrient Requirements of Domestic Animals. Nutrient Requirements of Beef Cattle. (6th Ed.). National Academy of Science-National Research Council, Washington, DC.

Crskov, E.R. 1982. Protein Nutrition in Ruminants. Academic Press, New York, NY.

Pacheco, M.E., R.D. Brown and R.I. Bingham. 1983. Nutritive value and intake of kleberg bluestem by beef cattle. J. Range Manage. 36:222. 
Pinney, D.O., D.F. Stephens and L.S. Pope. 1972. Lifetime effects of winter supplemental feed level and age at first parturition on range beef cows. J. Anim. Sci. $34: 1067$.

Poppi, D.P., D.J. Minson and J.H. Ternouth. 1981. Studies of cattle and sheep eating leaf and stem fractions of grasses. III. The retention time in the rumen of large feed particles. Aust. J. Agr. Res. 32:123.

Quicke, G.V., O.G. Bentley, H.W. Scott, R.R. Johnson and A.L. Moxon. 1959. Digestibility of soybean hulls and flakes and the in vitro digestibility of the cellulose in various milling by-products. J. Dairy Sci. 42:185.

Rakestraw, J., K.S. Lusby, R.P. Wettemann and J.J. Wagner. 1983. Effects of postpartum weight loss on performance of fall calving cows. Oklahoma Agr. Exp. Sta. Res. Rep. MP $-114: 218$.

Riggs, J.K. 1958. Fifty years of progress in the nutrition of beef cattle. J. Anim. Sci. 17:981.

Rittenhouse, L.R., D.C. Clanton and C.I. Streeter. 1970. Intake and digestibility of winter-range forage by cattle with and without supplements. J. Anim. Sci. $31: 1215$.

Scott, R.R. 1988. Effect of spring pasture burning, weaning date and supplemental protein source on performance, forage utilization and ruminal environment of fall-calving beef cattle maintained on native grass pastures in early summer. M.S. Thesis. Okla. State Univ., Stillwater, OK.

Speth, C.F., V.R. Bohman, H. Melendy and M.A. Wade. 1962. Effect of dietary supplements on cows on a semi-desert range. J. Anim. Sci. 21:444.

Steel, R.G.D. and J.H. Torrie. 1980. Principles and Procedures of Statistics (2nd Ed.). McGraw-Hill Book Co., New York.

Sudweeks, E.M. 1977. Digestibility by sheep of diets of citrus pulp, corn, or soybean mill feed with three forages. J. Dairy Sci. 60:1410.

Teeter, R.G., F.N. Owens and T.I. Mader. 1984. Ytterbium chloride as a marker for particulate matter in the rumen. J. Anim. Sci. 58:465. 
Thornton, R.F. and D.J. Minson. 1972. The relationship between voluntary intake and apparent retention time in the rumen. Aust. J. Agr. Res. 23:871.

Trautman, B.D. 1987. Forage utilization and productivity of lactating beef cows fed cottonseed meal, corn or soybean hull supplements during the winter. M.S. Thesis. Okla. State Univ.

Uden, P., P.E. Colucci and P.J. Van Soest. 1980. Investigation of chromium, cerium and cobalt as markers in digesta. Rate of passage studies. J. Sci. Food Agr. 31:625.

U.S.-CTFC. 1982. United States - Canadian Tables of Feed Composition. Third revision. National Academy Press, Washington, DC.

Van Keulen, J. and B.A. Young. 1977. Evaluation of acidnsoluble ash as a natural marker in ruminant digestibility studies. J. Anim. Sci. 44:282.

Van Soest, P.J. 1965. Symposium on factors influencing the voluntary intake of herbage by ruminants: voluntary intake in relation to chemical composition and digestibility. J. Anim. Sci. 24:834.

Van Soest, P.J. 1982. Nutritional Ecology of the Ruminant. $O$ and B Books, Corvallis, OR.

Varga, G.A. and E.C. Prigge. 1982. Influence of forage species and level of intake on ruminal turnover rates. J. Anim. Sci. 55:1498.

Wagner, D.G., J.K. Loosli, H.F. Hintz and R.G. Warner. 1965. Value of soybran flakes for milk production. J. Dairy Sci. 48:553.

Waldo, D.R. and H.K. Goering. 1979. Insolubility of proteins in ruminant feeds by four methods. J. Anim. Sci. $49: 1560$.

Waller, G.R., R.D. Morrison and A.B. Nelson. 1972. Chemical composition of native grasses in Central Oklahoma from 1947 to 1962. Okla. Agr. Exp. Sta. Bull. B-697.

Weston, R.H. and J.P Hogan. 1968. Factors limiting the intake of feed by sheep IV. The intake and digestion of mature ryegrass. Aust. J. agric. Res. 19:567. 
Wiedmeier, R.D., J.R. Males and C.T. Gaskins. 1983. Effect of dietary crude protein on the dry matter digestibility of wheat straw diets in cattle. J. Anim. Sci. $57: 1568$.

Wing, J.M. 1975. Effect of physical form and amount of citrus pulp on utilization of complete feeds for dairy cattle. J. Dairy Sci. 58:63.

Worrell, M.A., D.C. Clanton, W.W. Stroup and J.T. Nichols. 1986a. Effect of harvest date on meadow hay quality. I. Nutritional attributes, voluntary intake and rate of passage in growing cattle. J. Anim. Sci. 63:1527.

Worrell, M.A., D.C. Clanton, W.W. Stroup and J.T. Nichols. 1986b. Effect of harvest date on meadow hay quality. II. Particle size degradation and particulate passage from the rumen of growing cattle. J. Anim. Sci. $63: 1538$. 
APPENDIX

IN SITU HAY DIGESTIBILITY 
Rate of hay digestion was determined for each level of soybean hull supplementation with dacron bags ( $6 \times 10$ $\mathrm{cm}$; pore size 25 to $75 \mu \mathrm{m}$ ) filled with $2 \mathrm{~g}$ of native grass hay ground through a $1-\mathrm{mm}$ screen. Bags were secured to a weighted string $(50 \mathrm{~cm} ; 2-2 \mathrm{~cm}$ nuts attached; 2 bags/string) and placed at 0800 on d 10 and duplicates removed after $6,12,24,36,48$ and $96 \mathrm{~h}$ of incubation. Immediately after removal, bags were washed with lukewarm water until bag effluent was clear and then air dried (55 C). Empty bags subjected to ruminal incubation were also washed and dried to determine washout value of the bags. Bags and contents were frozen $(-15 \mathrm{C})$ prior to NDF analysis (Goering and Van Soest, 1970). Results were statistically analyzed utilizing the model described by Mertens and Loften (1980; table 9). Degradable OM or NDF content at any given time was calculated as the percent $O M$ or NDF disappearance divided by the $96 \mathrm{~h}$ disapperance. Rate of disappearance (DM and NDF) was determined by regressing the natural log of the residue (1-degradable OM or NDF) versus time. 
TABLE IX. IN SITU RATE AND EXTENT OF DISAPPEARANCE OF LOW-QUALITY GRASS HAY SUSPENDED IN THE RUMEN OF BEEF HEIFERS

\begin{tabular}{llllllll}
\hline & \multicolumn{3}{c}{ Soybean Hulls, $\mathrm{kg} / \mathrm{d}$} & & & Probability $^{\mathrm{a}}$ \\
\cline { 2 - 5 } Item & 0 & 1 & 2 & 3 & SEMb & Lin Quad Cub \\
\hline
\end{tabular}

Organic matter:

Degradable

$\begin{array}{lrrrrrrrr}\text { - } \% & 39.1 & 39.8 & 40.8 & 43.7 & 1.11 & .007 & .38 & .75 \\ \text { - Rate, \%/h } & 5.56 & 4.41 & 4.44 & 3.26 & .008 & .14 & .99 & .57\end{array}$

Total available

$\begin{array}{lllllllll}-\% & 49.7 & 50.5 & 51.6 & 54.7 & 1.11 & .007 & .38 & .75\end{array}$

Neutral detergent fiber:

Degradable

\begin{tabular}{lcccccccc}
$-\%$ & 48.0 & 49.4 & 50.4 & 53.4 & 1.14 & .006 & .55 & .66 \\
- Rate, \%/h & 4.16 & 4.19 & 3.73 & 3.04 & .006 & .26 & .62 & .94 \\
\hline
\end{tabular}

aprobability represents orthogonal contrasts for linear (Lin), quadratic (Quad) and cubic (Cub) treatment responses.

$\mathrm{b}_{\text {Standard error of the mean. }}$ 


$$
\begin{gathered}
\text { VITA } \\
\text { Stephanie Kim Long-Martin } \\
\text { Candidate for the Degree of } \\
\text { Master of Science }
\end{gathered}
$$

Thesis: INTAKE AND DIGESTIBILITY OF LOW-QUALITY NATIVE GRASS HAY BY BEEF COWS SUPPLEMENTED WITH GRADED LEVELS OF SOYBEAN HULLS

Major Field: Animal Science

Biographical:

Personal Data: Born in Chesapeake, Virginia, September 22, 1962, the daughter of Jim and Patricia Long. Married William (Bill) R. Martin, May 1985

Education: Graduated from B.T. Washington High School, Pensacola, Florida, May 1980. Received Associate of Arts in Animal Science from Northeastern A \& M College, Miami, Oklahoma, May 1982. Received Bachelor of Science in Animal Science from Oklahoma State University, May, 1984. Completed the requirements for the Master of Science Degree in Animal Science at Oklahoma State University, December, 1988.

Professional Experience: Worked at Oklahoma State University Feed Mill while an undergraduate, 1982 -1984. Laboratory Technician in Beef Cattle Nutrition Lab at Oklahoma State University Animal Science Department, 1984-1986. Veterinarian Technician at Cedar Village Animal Clinic, Norcross, Georgia, 1987-1988. 